\title{
Straightforward Access to Tetrametallic Complexes with a Square Array by Oxidative Dimerization of Organometallic Wires
}

\author{
Alexandre Burgun, ${ }^{\ddagger}{ }^{\dagger}$ Frédéric Gendron, ${ }^{\ddagger}$ Phil A. Schauer, ${ }^{\S}$ Brian W. Skelton, ${ }^{\ddagger}$ Paul J. Low, ${ }^{\S}$ Karine \\ Costuas, ${ }^{\ddagger}$ Jean-François Halet, ${ }^{*}$, Michael I. Bruce, ${ }^{* \dagger}$ and Claude Lapinte ${ }^{* \neq}$ \\ ${ }^{\ddagger}$ Institut des Sciences Chimiques de Rennes, UMR 6226 CNRS-Université de Rennes 1, F-35042 Rennes, France \\ ${ }^{\dagger}$ School of Chemistry and Physics, University of Adelaide, South Australia 5005, Australia \\ ${ }^{7}$ Centre for Microscopy, Characterisation and Analysis, University of Western Australia, Crawley, Western Australia 6009 \\ ${ }^{\S}$ Department of Chemistry, Durham University, South Road, Durham, DH1 3LE, U.K. \\ E-mail: jean-francois.halet@univ-rennes1.fr,michael.bruce@adelaide.edu.au,claude.lapinte@univ-rennes1.fr
}

\begin{abstract}
The bimetallic ruthenium complex $\{\mathrm{Cp}(\mathrm{dppe}) \mathrm{Ru}\}_{2}(\mu-\mathrm{C} \equiv \mathrm{CC} \equiv \mathrm{CC} \equiv \mathrm{C})(3, \mathrm{Cp}=$ cyclopentadienyl, dppe $=1,2-\mathrm{bis}-$ (diphenylphosphino)ethane) has been prepared and the molecular structure determined. The cyclic voltammogram of 3 is characterized by three reversible one-electron events with a large potential difference between the two first waves $\left(\Delta \mathrm{E}^{0}=0.44 \mathrm{~V}\right)$ indicating the large thermodynamic stability of the MV (mixed-valence) $3\left(\mathrm{PF}_{6}\right)$ which can be considered as a class III MV complex. The complex $3\left(\mathrm{PF}_{6}\right)$ was quantitatively prepared by treatment of 3 with 1 equiv of $\left[\mathrm{FeCp}_{2}\right]\left(\mathrm{PF}_{6}\right)$ at $-78{ }^{\circ} \mathrm{C}$ and characterized by EPR spectroscopy. Above $\quad-10 \quad{ }^{\circ} \mathrm{C}$, solutions of $3\left(\mathrm{PF}_{6}\right)$ provide the asymmetric tetranuclear complex \{cyclo$\mathrm{C}([\mathrm{Ru}]) \mathrm{C}(\mathrm{CCCC}[\mathrm{Ru}]) \mathrm{C}(\mathrm{CC}[\mathrm{Ru}]) \mathrm{C}(\mathrm{CC}[\mathrm{Ru}]\}\left(\mathrm{PF}_{6}\right)_{2}\left(4\left(\mathrm{PF}_{6}\right)_{2},[\mathrm{Ru}]=\mathrm{Cp}(\mathrm{dppe}) \mathrm{Ru}\right)$ which was formed regiospecifically and isolated in 92 $\%$ yield. Thus, despite the thermodynamic stability of the monocation radical $3\left(\mathrm{PF}_{6}\right)$ evidenced by the electrochemical data, and the extensively delocalized electronic structure, a slow dimerization reaction takes place affording a stable, tetranuclear complex. The new compound was characterized by single crystal X-ray diffraction study, cyclic voltammetry, multinuclear-NMR, IR, UV-vis and NIR spectroscopies and the data were analyzed with the support of quantum chemical investigations at the DFT level of theory. The regiospecificity of the dimerization reaction is controlled by a balance of steric and electronic factors, which favors intermolecular $(\mathrm{C} \alpha+$ C $\gamma$ ) radical coupling.
\end{abstract}

\section{INTRODUCTION}

Quantum-dot cellular automata (QCA) is a paradigm for nanoelectronics, in which binary information is encoded in charge configuration of a QCA cell and transferred via Coulomb interactions between neighboring cells. ${ }^{1,2}$ At the molecular level, the simplest molecular QCA cell is a symmetric mixedvalence complex in which the binary states 0 or 1 are represented by the location of a mobile electron (or a hole) at one metal center or at the other. ${ }^{3}$ However, square arrays with four redox sites are generally considered more versatile and efficient cell designs for use in logic applications. ${ }^{1,3}$

Several successful strategies for rational syntheses of tetrametallic complexes have been developed, but straightforward preparation of square arrays remains challenging., ${ }^{3,4}$ We may wonder if such square molecules - formally di-mixed-valence complexes - may be attained by oxidative dimerization of bimetallic mixedvalence derivatives. Considering that a wide variety of bimetallic complexes were prepared by ligand-ligand coupling via redox reactions this approach should be fruitful. ${ }^{5.7}$

In this respect, a wide variety of organometallic molecular wires in which two redox-active metal termini are connected through a bridging ligand has been developed. The wire-like performance of these linear species has been investigated in detail by means of various physical evaluation methods including rare measurements at the molecular level. ${ }^{8}$ Among these molecular wires, polyynediyl complexes, $\left[\mathrm{Cp}{ }^{\prime}(\mathrm{dppe}) \mathrm{M}-(\mathrm{C} \equiv \mathrm{C})_{\mathrm{m}^{-}}\right.$
$M($ dppe $\left.) C p^{\prime}\right]^{n+}(X)_{n}\left(C p^{\prime}=C p, C p^{*} ; M=F e, R u\right)$, exhibit the best performance with respect to interaction between the two metal centers through the bridge., 10 These compounds are ideally suited for conveying electronic coupling between the redox centers. These assemblies usually proved to be stable (and isolable) in different oxidation states for short carbon bridges $(m=1,2){ }^{11,12}$ However, previous studies have shown that the oxidized species from complexes with longer polyyne linkers have poor chemical stability. ${ }^{13} \mathrm{Up}$ to now, the complex $\left[\mathrm{Cp}^{*}(\mathrm{dppe}) \mathrm{Fe}-(\mathrm{C} \equiv \mathrm{C})_{4}-\mathrm{Fe}(\mathrm{dppe}) \mathrm{Cp}^{*}\right]^{\mathrm{n}^{+}}(\mathrm{X})_{\mathrm{n}}$ is the unique example of a kinetically stable mixed-valence complex with a $\mathrm{C}_{8}$-bridge. ${ }^{10}$ 14

Chart 1. Symmetric (A) and Asymmetric (B) Cyclobutenediylidene Complexes

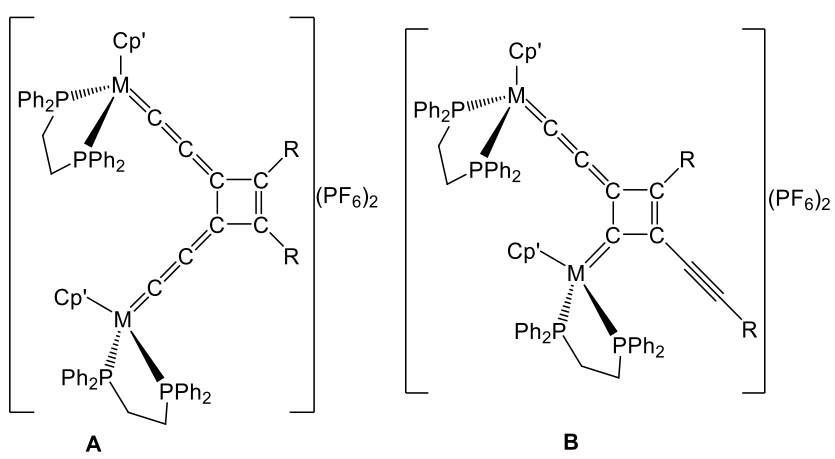


On the other hand, it has recently been found that the radical cations [Cp'(dppe)M-C $\equiv \mathrm{C}-\mathrm{C} \equiv \mathrm{C}-\mathrm{R}]\left(\mathrm{PF}_{6}\right)$ dimerize to afford the binuclear dications $\left[\{\mathrm{Cp} \text { '(dppe) } \mathrm{M}\}_{2} \mathrm{C}_{8} \mathrm{R}_{2}\right]\left(\mathrm{PF}_{6}\right)_{2}$ (Chart 1). Depending on the steric hindrance in the metal vicinity, the coupling involved either the inner and outer $\mathrm{C} \equiv \mathrm{C}$ triple bonds, to give a mixture of the symmetric and asymmetric cyclobutenediylidene complexes $\mathbf{A}$ and $\mathbf{B}\left(\mathrm{Cp}^{\prime}=\mathrm{Cp}, \mathrm{M}=\mathrm{Ru}\right)$ or regiospecifically at the outer triple bonds to give the symmetric isomer $\mathrm{A}$ as the unique product $\left(\mathrm{Cp}^{\prime}=\mathrm{Cp}^{*}, \mathrm{M}=\mathrm{Fe}\right.$, Scheme 1). ${ }^{16}$ In addition, a recent experimental and theoretical investigation on the iron and ruthenium $\sigma$-polyynyl complexes has concluded that iron(III) and ruthenium(III) radicals may react via a clean chemical process, since the ESR signal disappeared clearly upon warming, no trace of other radicals being detected. ${ }^{17}$

\section{Scheme 1. Possible Self-Coupling of $\left\{[\mathrm{M}]-(\mathrm{C} \equiv \mathrm{C})_{3}-[\mathrm{M}]\right\}^{+}$}
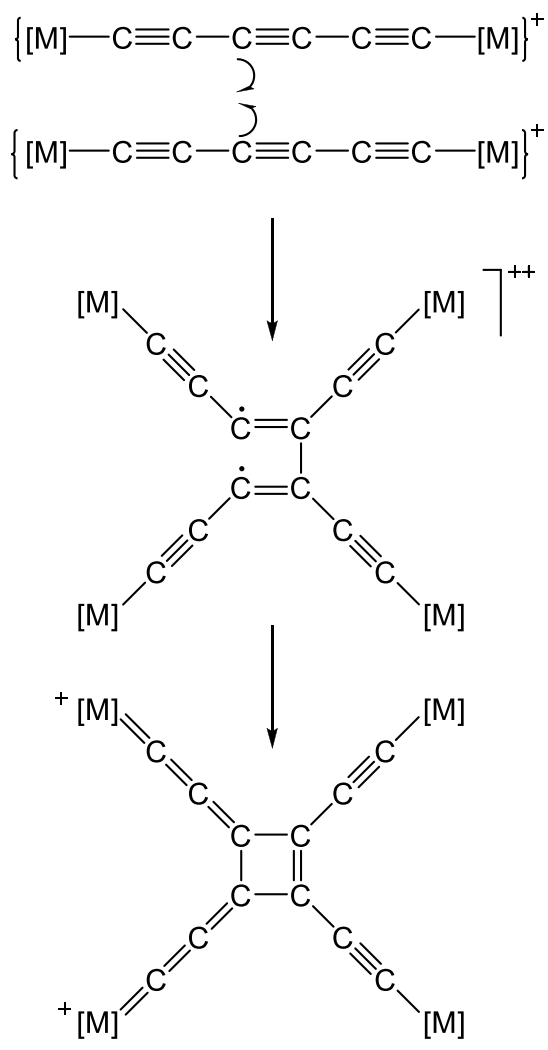

As it is well established that polyynediyl-bridged mixedvalence complexes are often chemically unstable, ${ }^{10}$ the chemistry of these radical species has not been extensively investigated. ${ }^{13}$ Guided by the stimulating results on the reactivity of mononuclear complexes bearing butadiynyl ligands, ${ }^{7,}{ }^{15-17}$ we have investigated the reactivity of symmetric mixed-valence complexes $\left[\mathrm{Cp}(\mathrm{dppe}) \mathrm{Ru}-(\mathrm{C} \equiv \mathrm{C})_{3}-\mathrm{Ru}(\mathrm{dppe}) \mathrm{Cp}\right]\left(\mathrm{PF}_{6}\right)$. In these compounds the metal centers are linked by a $\mathrm{C}_{6}$ carbon bridge, which seems to be ideally suited for providing tetrametallic complexes with a square array upon regio-specific oxidative coupling of two of these binuclear hexatrynediyl complexes.
With reference to our previous work on the oxidative activation of arylbutadiynyl-metal complexes, ${ }^{15,16}$ it can be anticipated that dimerization of the radical cation $\left\{[\mathrm{M}]-(\mathrm{C} \equiv \mathrm{C})_{3}-[\mathrm{M}]\right\}^{+}$might occur through $(\mathrm{C} \gamma+\mathrm{C} \gamma)$ coupling to afford a symmetric tetranuclear complex with a square core as depicted in Scheme 1.

We report here the synthesis of the bis(ruthenium) hexatriynediyl complex $\{\mathrm{Cp}(\mathrm{dppe}) \mathrm{Ru}\}_{2}(\mu-\mathrm{C} \equiv \mathrm{CC} \equiv \mathrm{CC} \equiv \mathrm{C})(3)$, the low temperature preparation and in situ characterization of the related mixed-valence complex $3\left(\mathrm{PF}_{6}\right)$ as well as the regiospecific dimerization of the radical cation which affords the asymmetric tetranuclear complex $\left[\{\mathrm{Cp}(\mathrm{dppe}) \mathrm{Ru}\}_{4}\left\{\mu-\mathrm{C}_{12}\right\}\right]\left(\mathrm{PF}_{6}\right)_{2} \quad\left[4\left(\mathrm{PF}_{6}\right)_{2}\right]$. The full characterization of the tetranuclear dications, including an X-ray analysis of the metathetized salt $4\left(\mathrm{AsF}_{6}\right)_{2}$, electrochemical data, spectroscopic properties and a rationalization of the mechanism of the reaction and the physical properties of $4^{2+}$ by quantum chemical investigations at the DFT level are also reported and discussed.

\section{RESULTS AND DISCUSSION}

1. Synthesis of the Binuclear Complexes 3. Only few methods are available for the preparation of symmetric binuclear hexatriynediyl complexes. ${ }^{18}$ The most widely used method is the reaction between a metal halide and the TMS-protected hexatriyne $\mathrm{Me}_{3} \mathrm{Si}-(\mathrm{C} \equiv \mathrm{C})_{3}-\mathrm{SiMe}_{3}$ in the presence of a desilylating agent such as KF. This reaction is very efficient because the bimetallic complex $[\mathrm{M}]_{2}(\mu-\mathrm{C} \equiv \mathrm{CC} \equiv \mathrm{CC} \equiv \mathrm{C})$ generally precipitates out of solution and no further purification is needed.

Scheme 2. Synthesis of diruthenium Complex 3

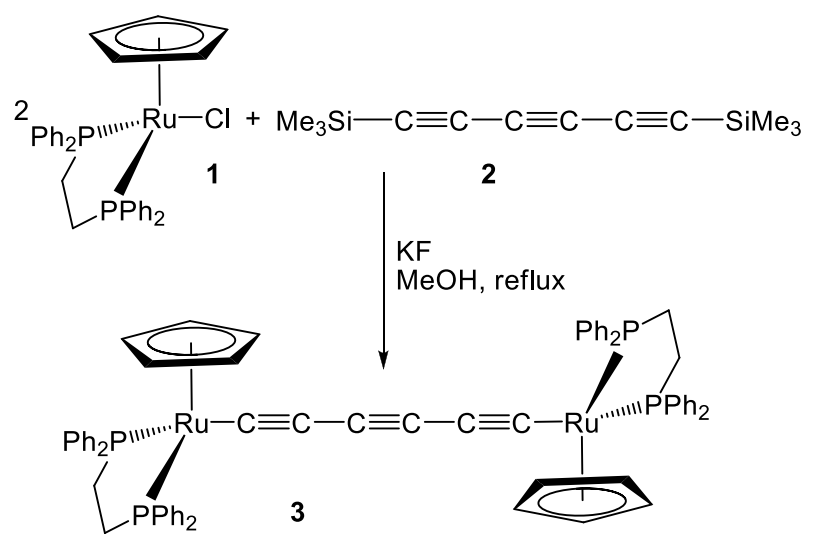

Accordingly, treatment of bis(trimethylsilyl)hexatriyne (2) with two equivalents of $\mathrm{RuCl}(\mathrm{dppe}) \mathrm{Cp}$ (1) in refluxing methanol affords the bis(ruthenium) complex $\{\mathrm{Cp}(\mathrm{dppe}) \mathrm{Ru}\}_{2}(\mu-$ $\mathrm{C} \equiv \mathrm{CC} \equiv \mathrm{CC} \equiv \mathrm{C}$ ) (3) in a pure form after only an hour (Scheme 2, $80 \%$ yield).

The bimetallic complex 3 was characterized by the usual spectroscopic methods. The IR spectrum of 3 in $\mathrm{CH}_{2} \mathrm{Cl}_{2}$ exhibits a single ${ }_{\mathrm{C} \equiv \mathrm{C}}$ band at $2063 \mathrm{~cm}^{-1}$. In the ${ }^{1} \mathrm{H}$ NMR spectrum, the $\mathrm{Cp}$ resonance was observed at 4.56 (s) while the dppe- $\mathrm{CH}_{2}$ groups gave multiplets at $1.84-1.87$ and $2.43-2.46$. The 
$\mathrm{Ru}(\mathrm{dppe}) \mathrm{Cp}$ fragment was also observed in the ${ }^{13} \mathrm{C}$ NMR spectrum, with $\mathrm{Cp}$ at 83.16 (s), $\mathrm{CH}_{2}$ of the dppe between 28.23. 28.53 as a multiplet; $\mathrm{C}$ of the carbon chain was a triplet coupled to the two phosphorus atoms of the dppe at $102.64\left({ }^{2} J_{\mathrm{CP}}\right.$ $=28 \mathrm{~Hz}$ ). The ${ }^{31} \mathrm{P}$ NMR spectrum displayed one peak at 85.8 corresponding to the four equivalent phosphorus atoms of the molecule.

The initial scan in the cyclic voltammogram of complex 3 from -0.5 to $1.5 \mathrm{~V}$ [vs the standard calomel electrode (SCE)] is characterized by three well-separated one-electron processes (Table 1). While the third oxidation wave is only partially reversible $\left(E_{3}=1.11 \mathrm{~V}\right)$, the two first oxidation waves $\left(E_{1}^{0}=\right.$ $0.01 \mathrm{~V}, E_{2}^{0}=0.45 \mathrm{~V}$ ) are fully reversible indicating that the neutral dimer 3 undergoes two successive and reversible oneelectron oxidations to yield the mono- and dications in the vicinity of the electrode. The large potential difference $\left(\Delta E^{0}=\right.$ $0.44 \mathrm{~V}$ ) which corresponds to a large comproportionation constant $\left(K_{c}=2.9 \times 10^{7}\right)$ indicates the large thermodynamic stability of the mixed-valence derivative $3\left(\mathrm{PF}_{6}\right)$ with respect to the homovalent complexes 3 and $3\left(\mathrm{PF}_{6}\right)_{2}$. Moreover, the very large $\Delta E^{0}$ value is diagnostic of strong electronic interactions between the two metal centers through the hexatriynediyl bridge and complex $3\left(\mathrm{PF}_{6}\right)$ can be considered as a class III delocalized mixed-valence complex. ${ }^{6,19}$ Attempts to isolate this compound were unsuccessful, although it was possible to acquire in-situ EPR spectra, and follow the progress of the subsequent chemical reactions of $3\left(\mathrm{PF}_{6}\right)$.

2. In Situ Glass EPR Spectroscopy of $3\left(\mathrm{PF}_{6}\right)$. Complex 3 was reacted with 1 equiv. of $\left[\mathrm{FeCp}_{2}\right]\left(\mathrm{PF}_{6}\right)$ in $\mathrm{CH}_{2} \mathrm{Cl}_{2}$ at $-78^{\circ} \mathrm{C}$ under inert atmosphere. The color of the solution changed from yellow to deep red indicating the formation of the mixedvalence complex $3\left(\mathrm{PF}_{6}\right)$. After one hour at $-78^{\circ} \mathrm{C}$, an aliquot of the solution was transferred to a quartz EPR tube and immediately cooled down to liquid nitrogen temperature, thereby forming a glass. The X-band EPR spectrum of the radical cation at $66 \mathrm{~K}$ displays three well-resolved features $\left(g_{1}=2.253, g_{2}=\right.$ 2.047, $\left.g_{3}=1.985\right)$ corresponding to the components of a $g$ tensor characteristic of $\mathrm{d}^{5}$ low-spin $\mathrm{Ru}(\mathrm{III})$ in a pseudooctahedral environment. ${ }^{20}$ No hyperfine coupling between the unpaired electron and phosphorus was observed.

The calculated $g_{\text {iso }}$ value $\left(g_{\text {iso }}=1 / 3\left(g_{1}+g_{2}+g_{3}\right)=2.095\right)$ for $3\left(\mathrm{PF}_{6}\right)$ is very close to the value previously measured for the related mixed-valence butadiynediyl complex $\left[\left\{\mathrm{Cp}^{*}(\mathrm{dppe}) \mathrm{Ru}\right\}_{2}(\mu-\mathrm{C} \equiv \mathrm{CC} \equiv \mathrm{C})\right]\left(\mathrm{PF}_{6}\right)\left(g_{\text {iso }}=2.096\right),{ }^{21}$ but significantly larger than the value determined for the mononuclear butadiynyl complex $\left[\mathrm{Cp}^{*}(\mathrm{dppe}) \mathrm{RuC} \equiv \mathrm{CC} \equiv \mathrm{CPh}\right]\left(\mathrm{PF}_{6}\right) \quad\left(g_{\text {iso }}=\right.$ 2.074). ${ }^{17}$ The larger $g_{\text {iso }}$ values found for the bimetallic compounds suggest that the SOMO containing the unpaired electron has greater ruthenium character in the bimetallic complexes relative to the mononuclear derivatives.

The small tensor anisotropy $\left(\Delta g=g_{1}-g_{3}\right)$ also supports the class III character of the mixed-valence $3\left(\mathrm{PF}_{6}\right)$. Indeed, in a homologous series of mixed-valence compounds the anisotropy tensor of the EPR signal decreases as the rate of the intramolecular electron transfer increases. ${ }^{22}$ Relative to the tensor anisotropy found in $\left[\mathrm{Cp}^{*}(\mathrm{dppe}) \mathrm{RuC} \equiv \mathrm{CC} \equiv \mathrm{CPh}\right]\left(\mathrm{PF}_{6}\right) \quad(\Delta g=$ 0.420), ${ }^{17}$ a value close to that expected for a localized mixedvalence complex with related ruthenium termini, the tensor anisotropy of $3\left(\mathrm{PF}_{6}\right)$ is small $(\Delta g=0.268)$ and close to the that obtained for the related complex $\left[\left\{\mathrm{Cp}^{*}(\mathrm{dppe}) \mathrm{Ru}\right\}_{2}(\mu\right.$ $\mathrm{C} \equiv \mathrm{CC} \equiv \mathrm{C})]\left(\mathrm{PF}_{6}\right)(\Delta g=0.232){ }^{21}$

3. Synthesis of the tetranuclear complexes $4\left(\mathrm{PF}_{6}\right)_{2}$ and $4\left(\mathrm{AsF}_{6}\right)_{2}$. Solutions of $3\left(\mathrm{PF}_{6}\right)$ can be kept for hours below -25 ${ }^{\circ} \mathrm{C}$, but when the temperature reached $-10{ }^{\circ} \mathrm{C}$, the color of the solution changed from deep red to deep blue indicating a further reaction. After one hour at room temperature to reach completion, hexane was added to afford $4\left(\mathrm{PF}_{6}\right)_{2}$ as a deep blue powder in $92 \%$ yield.

Scheme 3. Synthesis of tetraruthenium Complex $4\left(\mathrm{PF}_{6}\right)_{2}$

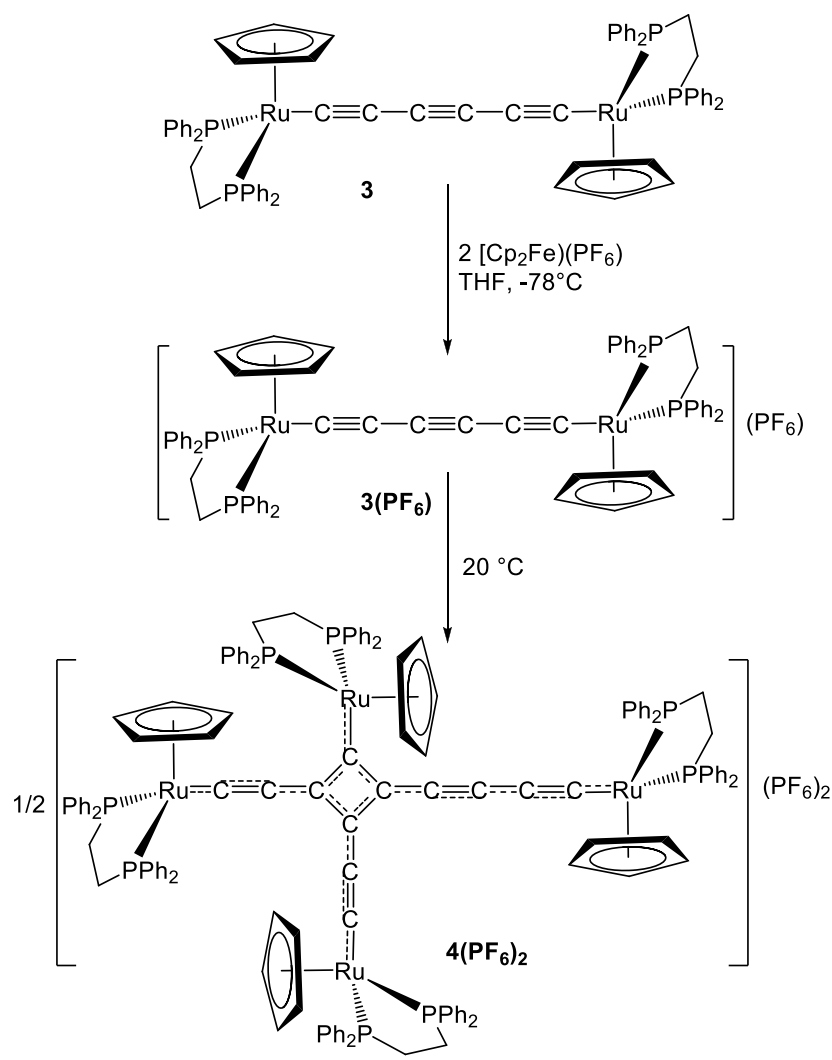

The dimeric structure of $4\left(\mathrm{PF}_{6}\right)_{2}$ was established by high resolution mass spectrometry of the dication at $\mathrm{m} / z 1201.740(z=$ 2; calculated: 1201.661 for $\left.[\mathrm{M}]^{2+}\right)$. The ${ }^{1} \mathrm{H}$ NMR spectrum of $4\left(\mathrm{PF}_{6}\right)_{2}$ displays four distinct resonances for the $\mathrm{Cp}$ ligands at $4.86[\mathrm{~s}(\mathrm{br})], 5.15(\mathrm{~s}), 5.20(\mathrm{~s})$ and 5.64 [s(br)] with the same relative intensities showing that the four metal centers of the tetranuclear complex $4\left(\mathrm{PF}_{6}\right)_{2}$ are not equivalent. Clearly, the formation of a symmetric dimer, which is expected to be formed via $(\mathrm{C} \gamma+\mathrm{C} \gamma)$ coupling has not occured. It can be observed that the chemical shifts of the $\mathrm{Cp}$ protons are very close to each other, and as a consequence the two positive charges are probably delocalized over the four $\mathrm{Cp}(\mathrm{dppe}) \mathrm{Ru}$ centers.

The ${ }^{31} \mathrm{P}$ NMR spectrum of $4\left(\mathrm{PF}_{6}\right)_{2}$ recorded at $20^{\circ} \mathrm{C}$ contains only one unresolved, very broad and weak signal in the 80 95 region. In contrast, the signal of the $\mathrm{PF}_{6}$ anions appears as a very well resolved septuplet $\left({ }^{1} J_{\mathrm{PF}}=710 \mathrm{~Hz}\right)$ centered at -143.2 . 
It was suspected that the low resolution of the NMR spectrum has its origin in slow molecular motions. In order to improve the resolution of the signal corresponding to the dppe ligands, low temperature ${ }^{31} \mathrm{P}$ NMR spectra were then measured. The ${ }^{31} \mathrm{P}$ NMR spectrum of $4\left(\mathrm{PF}_{6}\right)_{2}$ run at $-80^{\circ} \mathrm{C}$ contains three resolved broad peaks at $80.7,85.3$ and 94.8 (relative intensities 1:2:1, respectively), consistent with the presence of only one product resulting from the initial $(\mathrm{C} \alpha+\mathrm{C} \gamma)$ regioselective coupling as shown in Scheme 3. The more intense signal at 85.3 can be assigned to the dppe phosphorus atoms of the two $-\mathrm{C}_{2}$ $\mathrm{Ru}(\mathrm{dppe}) \mathrm{Cp}$ fragments. The peak centered at 94.8 is assigned to the $\mathrm{Ru}(\mathrm{dppe}) \mathrm{Cp}$ directly attached to the $\mathrm{C}_{4}$ ring; ${ }^{31} \mathrm{P}$ NMR chemical shifts of the dppe phosphorus atoms of similar ruthenium moieties attached to $\mathrm{C}$, are centered in the $90-100$ region. $^{23}$ De facto, the last signal at 80.7 is assigned to the fourth $\mathrm{Ru}(\mathrm{dppe}) \mathrm{Cp}$ fragment, attached to the cyclobutene ring through the $\mathrm{C}_{4}$ chain.

In the ${ }^{13} \mathrm{C}$ NMR spectrum, recorded at room temperature, very weak and broad unresolved signals were observed at 227.81, 258.64, 226.10, 187.15 and 159.69, which could be assigned to the $\mathrm{C}$ atoms directly attached to the $\mathrm{Ru}(\mathrm{dppe}) \mathrm{Cp}$ centers, together with some $s p$ carbons of the chains. Other signals were found in the aromatic region as multiplets between

125.59 and 143.39 , which could be assigned to the phenyl groups of the dppe ligands and some carbons of the $\mathrm{C}_{12}$ ligand. The Cp carbon atoms were observed as four singlets (three wellresolved) at $86.62,87.04,88.26$ (br) and 89.49 for the four different $\mathrm{Ru}(\mathrm{dppe}) \mathrm{Cp}$ fragments. In accord with the ${ }^{1} \mathrm{H}$ data, the chemical shifts of the $\mathrm{Cp}$ carbon atoms are between those of neutral $\mathrm{Ru}(\mathrm{II})(\mathrm{dppe}) \mathrm{Cp}$ and cationic $[\mathrm{Ru}(\mathrm{II})(\mathrm{dppe}) \mathrm{Cp}]^{+}$moieties. Finally, the $\mathrm{CH}_{2}$ groups of the dppe ligand were observed as multiplets between 27.70 and 31.46. Additionally, no sp carbon resonance was observed in the usual $\mathrm{C} \equiv \mathrm{C}$ triple bond range.

The new tetranuclear dimer $4\left(\mathrm{PF}_{6}\right)_{2}$ was further characterized by IR spectroscopy in solution $\left(\mathrm{CH}_{2} \mathrm{Cl}_{2}\right)$ and in the solid state (Nujol) in order to observe and hopefully assign the different multiple bonds in the molecule. In the IR spectrum recorded in Nujol, two cc vibrations were observed at 2069(m) and 1941(s) $\mathrm{cm}^{-1}$ while the $\mathrm{pF}$ band was displayed at $836 \mathrm{~cm}^{-1}$. Given the low symmetry of the molecule, the presence of only two (CC) bands in the IR spectrum is probably indicative of a large delocalization of the charges on the whole structure in accord with the X-ray diffraction data (see below). In contrast, the IR spectrum of a dichloromethane solution of $4\left(\mathrm{PF}_{6}\right)_{2}$ displays four absorption bands in the multiple carbon-carbon bond stretching region: a medium band at $2072 \mathrm{~cm}^{-1}$ and three bands at 1984 (sh), 1960, and $1929 \mathrm{~cm}^{-1}$ (see Figures S1 and S3). Observation of two additional bands in the spectrum run in solution, is consistent with the observation of the broad weak signal in the ${ }^{31} \mathrm{P}$ NMR spectrum recorded at $20^{\circ} \mathrm{C}$ which was resolved in the spectrum run at $-80^{\circ} \mathrm{C}$ (see above). In solution, the $\mathrm{Cp}(\mathrm{dppe}) \mathrm{Ru}$ fragments freely rotate around the $\mathrm{C}_{4}$ ring and the IR spectrum can sample all of the available conformations, while the thermodynamically more stable conformer is quenched in the solid state as observed in the molecular structure of $4\left(\mathrm{AsPF}_{6}\right)_{2}$.
4. Molecular Structures of 3 and $4\left(\mathrm{AsF}_{6}\right)_{2}$. Suitable crystals of 3 for X-ray analyses were obtained by slow diffusion of hexane into a benzene solution. An ORTEP view of 3 is illustrated in Figure 1 and key structural parameters are collected in Table S1 (in connection with Section 5). The asymmetric unit contains one molecule of 3 and half a molecule of benzene.

As expected, bond lengths in the $\mathrm{Ru}(\mathrm{dppe}) \mathrm{Cp}$ fragment are typical while angles confirm the pseudo-octahedral geometry of the metal atoms. Distances along the carbon chain confirm its hexatriynediyl nature with $\mathrm{C} \equiv \mathrm{C}$ triple bond lengths being between 1.213(9) - 1.221(9) $\AA$ and C-C single bond distances being $1.385(9)$ and $1.376(10) \AA$. It is noteworthy that the Ru$\mathrm{C}_{6}-\mathrm{Ru}$ chain deviates significantly from linearity showing a symmetric "bow" conformation ${ }^{24}$ with the angle between the $\mathrm{Ru}(1)-\mathrm{C}(1)$ and $\mathrm{C}(6)-\mathrm{Ru}(2)$ bond vectors being $34^{\circ}$ as illustrated in Figure 1.

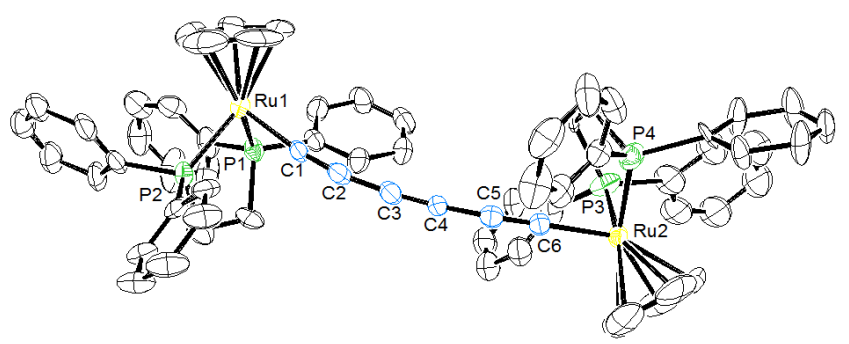

Figure 1. ORTEP representation of $\{\mathrm{Cp}(\mathrm{dppe}) \mathrm{Ru}\}_{2}(\mu-$ $\mathrm{C} \equiv \mathrm{CC} \equiv \mathrm{CC} \equiv \mathrm{C})(3)$ at $50 \%$ probability level. Hydrogen atoms and solvent molecule have been removed for clarity.

Deep blue crystals of $4\left(\mathrm{AsF}_{6}\right)_{2}$ were obtained by slow diffusion of benzene into a concentrated solution in dichloromethane, the more bulky $\left(\mathrm{AsF}_{6}\right)^{\prime}$ anions facilitating crystallization. However, the crystals were very prone to desolvation when out of the mother liquor. An ORTEP view of the asymmetric dication $4\left(\mathrm{AsF}_{6}\right)_{2}$ is shown in Figure 2, while selected key parameters are collected in Table S2. The asymmetric unit consists of one molecule of $4\left(\mathrm{AsF}_{6}\right)_{2}$, two molecules of dichloromethane and four and a half molecules of benzene.

The X-ray analysis confirmed that $4\left(\mathrm{AsF}_{6}\right)_{2}$ contains four nonequivalent $\mathrm{Ru}(\mathrm{dppe}) \mathrm{Cp}$ fragments and one cyclobutene center as depicted in Scheme 3. The surprising asymmetric geometry of the molecule established from the spectroscopic data is confirmed: two metal fragments are attached to the cyclobutene ring through $\mathrm{C}_{2}$ chains, while the two others are connected either through a $\mathrm{C}_{4}$ chain or directly to the cyclobutene center. The $\mathrm{C}_{4}$ ring slightly deviates from a perfect square, with angles in the range of $86.4(5)-93.3(6)^{\circ}$ (sum of angles $=360^{\circ}$ ) and $\mathrm{C}$ $\mathrm{C}$ bond lengths between $1.452(10)$ and $1.507(10) \AA$. The three carbon chains $\mathrm{Ru}(1)-\mathrm{C}(1-3), \mathrm{Ru}(2)-\mathrm{C}(8-4)$ and $\mathrm{Ru}(4)-\mathrm{C}(11-9)$ are nearly linear, with angles being between $170.1(8)$ and $177.5(7)^{\circ}$, apart from the small bending at the end of the $\mathrm{C}_{4}$ chain. The $\mathrm{C}_{12}$ ligand is approximately planar, with the major bending at $\mathrm{C}(8)$ : A plane through the atoms $\mathrm{C}(1-5)$ and $\mathrm{C}(9-12)$ shows deviations of the other atoms $\mathrm{C}(6), \mathrm{C}(7), \mathrm{C}(8)$ of $0.05(1)$, $0.17(1), 0.34(1) \AA$, respectively. As expected, the four ruthenium atoms adopt a pseudo-octahedral geometry; however, the angles $\mathrm{C}(12)-\mathrm{Ru}(3)-\mathrm{P}(5)=91.6(2)$ and $\mathrm{C}(12)-\mathrm{Ru}(3)-\mathrm{P}(6)=$ 
$90.0(2)^{\circ}$ at the $\mathrm{Ru}(3)$ atom are larger than in the other $\mathrm{Ru}(\mathrm{dppe}) \mathrm{Cp}$ fragments. This is probably due to steric hindrance [the $\mathrm{Ru}(3)(\mathrm{dppe}) \mathrm{Cp}$ fragment is directly attached to the $\mathrm{C}_{4}$ ring]. Distances in the four $\mathrm{Ru}(\mathrm{dppe}) \mathrm{Cp}$ fragments are very similar, the Ru-P bond lengths being in the range 2.256(2) 2.293(2) A, somewhat longer than in typical neutral $\mathrm{Ru}(\mathrm{II})(\mathrm{dppe}) \mathrm{Cp}$ complexes such as 3 (see above), and shorter than those found in typical cationic $[\mathrm{Ru}(\mathrm{II})(\mathrm{dppe}) \mathrm{Cp}]^{+}$complexes $(\mathrm{Ru}-\mathrm{P} \approx 2.30 \AA) .{ }^{25}$ Similarly, the Ru-C(chain) bond lengths are between 1.916(8) and 1.948(7) $\AA$, which lie between typical $[\mathrm{Ru}(\mathrm{II})=\mathrm{C}(\mathrm{dppe}) \mathrm{Cp}]^{+}(\approx 1.85 \AA)$ and $\mathrm{Ru}(\mathrm{II})-\mathrm{C}(\mathrm{dppe}) \mathrm{Cp}(\approx 2.00$ A) distances. The C-C distances within the carbon chains (two $\mathrm{C}_{2}$ and one $\mathrm{C}_{4}$ ) of the $\mathrm{C}_{12}$ ligand are also very similar, the formal $\mathrm{C} \equiv \mathrm{C}$ triple bonds are slightly elongated [1.229(10) 1.254(11) A] while the formal C-C single bonds are slightly shortened [1.343(10) - 1.382(10) $\AA$ ]. Distances in the cyclobutene ring [range $1.452(10)-1.507(10) \AA$ ] are also between $\mathrm{C}=\mathrm{C}$ double and C-C single bonds, C(3)-C(12) = 1.507(10) A corresponding to a C-C single bond. The distances in the $\mathrm{Ru}(\mathrm{dppe}) \mathrm{Cp}$ fragments are between typical Ru(II)(dppe)Cp and $[\mathrm{Ru}(\mathrm{II})(\mathrm{dppe}) \mathrm{Cp}]^{+}$bond lengths and together with the distances found in the $\mathrm{C}_{12}$ ligand indicate that the positive charges are not localized on two metal centers, as it might be expected for an asymmetric complex, but are delocalized on the whole molecule on the X-ray time scale. This last observation makes it difficult to represent the bonding of $4\left(\mathrm{AsF}_{6}\right)_{2}$ with a single Lewis formula; thus it has been drawn as fully delocalized in Scheme 3. The deviations from a plane of best fit through the four $\mathrm{Ru}$ atoms are $\mathrm{Ru}(1)-0.199(1), \mathrm{Ru}(2)-0.145(1) \AA$ on one side of the plane and $\mathrm{Ru}(3) 0.208(1)$ and $\mathrm{Ru}(4) 0.137(1) \AA$ on the other side, showing a small but significant tetrahedral distortion. Apart from $\mathrm{C}(1)$ and $\mathrm{C}(2)$, all the remaining carbon atoms of the cyclobutenediyylidene ligand lie on the $\mathrm{Ru}(3) / \mathrm{Ru}(4)$ side of the $\mathrm{Ru}_{4}$ plane with deviations from the plane ranging from $0.08-0.29(1) \AA$. The deviations of $\mathrm{C}(1)$ and C(2) are -0.05 and $-0.01(1) \AA$ respectively.

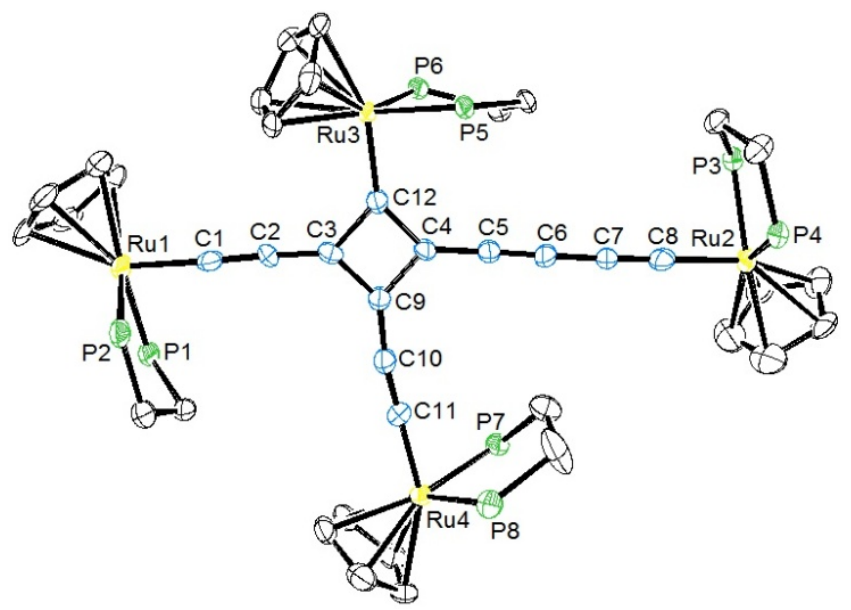

Figure 2. ORTEP representation of $\left[\{\mathrm{Cp}(\mathrm{dppe}) \mathrm{Ru}\}_{4}\{\mu\right.$ $\left.\left.\mathrm{C}_{12}\right\}\right]\left(\mathrm{AsF}_{6}\right)_{2}\left(4\left(\mathrm{AsF}_{6}\right)_{2}\right)$ at $50 \%$ probability level. Hydrogen atoms, phenyl groups of the dppe ligand, $\mathrm{AsF}_{6}$ anions, and solvent molecules have been removed for clarity.

5. Proposed Mechanism for the Formation of $4^{2+}$. In order to better understand the formation of the new tetrametallic compound $4\left(\mathrm{XF}_{6}\right)_{2}\left(\mathrm{X}=\mathrm{PF}_{6}, \mathrm{AsF}_{6}\right)$ the bimetallic precursor 3 and its related MV complex $3^{+}$were firstly optimized at the DFT level of theory (see Computational Details). The resulting geometrical data are provided in Supporting Information (Table S1). The optimized bond lengths compare rather well with the available experimental values. In 3 , the $\mathrm{Ru}-\mathrm{C}$ and $\mathrm{C} \equiv \mathrm{C}$ distances are slightly overestimated by $0.025 \AA$ and $0.030 \AA$, respectively, whereas the single $\mathrm{C}-\mathrm{C}$ bonds are computed shorter by $0.033 \AA$ compared to the X-ray data. As already found in previous theoretical studies, ${ }^{15}, 17$ the largest discrepancy is found for the Ru-Cp and Ru-P bond lengths, which are overestimated by $0.13 \AA$ and $0.05 \AA$, respectively. Upon oxidation, the Ru-C distances strongly decrease, from $2.021 \AA$ to $1.996 \AA$, when going from 3 to $3^{+}$, respectively. To a lesser extent, a shortening of the single C-C bonds $(0.026 \AA)$ and a lengthening of the triple $\mathrm{C} \equiv \mathrm{C}$ bonds $(0.016 \AA)$ are also observed upon the oxidation of 3, leading to a carbon spacer with a greater cumulenic character. In agreement with these geometrical changes, a decrease of the $\mathrm{v}_{\mathrm{C} \equiv \mathrm{C}}$ stretching modes is observed, upon oxidation (Table S1). These trends are commonly observed for these polyynediyl complexes and can be understood with a glance at the nodal properties of their first highest occupied molecular orbitals (HOMOs). As previously detailed for related bimetallic systems, ${ }^{12}$ the first HOMOs of these systems are fully delocalized all over the $\mathrm{Ru}-\mathrm{C}_{6}-\mathrm{Ru}$ backbone and are $\pi$-type in character. Furthermore, they are antibonding along the Ru-C and C-C single bonds and bonding along the $\mathrm{C} \equiv \mathrm{C}$ triple bonds (see Figure S1).

The spatial spin distribution calculated for the cationic complex $3^{+}$is pictured in Figure 3. The largest values of the atomic spin density are found on the ruthenium atoms $(0.17$ e per metal). However, the spin density is also largely distributed all over the carbon linker with substantial atomic spin densities located on $\mathrm{C} \alpha$ (0.12 e), and to a lesser extent on $\mathrm{C} \beta$ (0.08 e) and $\mathrm{C} \gamma(0.09 \mathrm{e})$. This spin-density distribution is consistent with the computed EPR properties of $3^{+}$, with $g_{1}=2.386, g_{2}=$ 2.004 and $g_{3}=1.950$, corresponding to an unpaired electron mainly localized on the metallic fragments. ${ }^{17}$

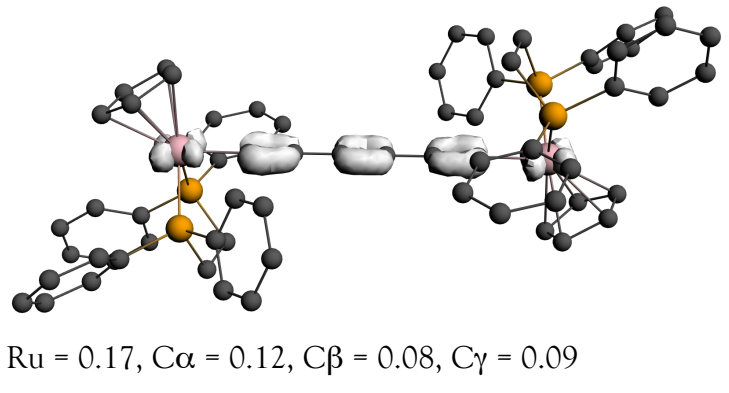

Figure 3. Spatial distribution of the computed spin density of $3^{+}$ (isocontour value $\pm 0.005 \mathrm{e} / \mathrm{bohr} 3$ ). Atomic spin densities (electrons) are given.

The distribution of the spin density in $3^{+}$allows us to tentatively propose a mechanism for the formation of the tetrametallic complexes $4^{2+}$. Indeed, the strong delocalization of the spin density all over the metal-bridge-metal skeleton in $3^{+}$must strongly increase its reactivity and suggests that several routes 
are electronically possible for a radical coupling process. However, as previously shown for the dimerization of related arylalkynyl-metal complexes, the $(\mathrm{Ru}+\mathrm{Ru})$ and $(\mathrm{C} \alpha+\mathrm{C} \alpha)$ radical coupling processes are strongly disfavored due to the steric protection of the bulky dppe ligands. ${ }^{15}$ Consequently, the most plausible routes to consider are that of $(C \gamma+C \gamma)$ and $(C \alpha+C \gamma)$ coupling, which result in the formation of symmetric and asymmetric tetra-metallic products respectively (Route $A$ and Route B in Scheme 4).

Surprisingly enough, only the asymmetric tetrametallic isomer (formed by Route B), is found experimentally. This result may appear counterintuitive at first sight and suggests that the dimerization process of $3^{+}$, and thus the formation of $4^{2+}$, is controlled by a balance of steric and electronic factors which in combination favors $(\mathrm{C} \alpha+\mathrm{C} \gamma)$ radical coupling. Indeed, $(\mathrm{C} \alpha+$ $\mathrm{C} \alpha)$ coupling should be electronically preferred whereas $(\mathrm{C} \gamma+$ $\mathrm{C} \gamma$ ) coupling should be sterically favored.

\section{Scheme 4. Radical Coupling of $\left\{[\mathrm{Ru}]-(\mathrm{C} \equiv \mathrm{C})_{3}-[\mathrm{Ru}]\right\}^{+}$}

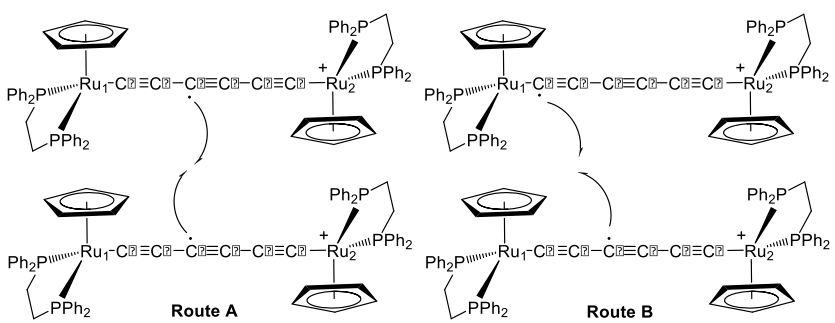

6. Electronic Properties of $4^{\mathrm{n}+}(n=1-3)$. DFT calculations were carried out on $4^{2+}$ to characterize its electronic properties. Metrics optimized for its singlet spin configuration, given in the Supporting Information, reproduce satisfactorily the values experimentally measured for $4\left(\mathrm{AsF}_{6}\right)_{2}$. The calculated $\mathrm{Ru}-\mathrm{Cp}$ (centroid) and Ru-P distances are somewhat overestimated with respect to the experimental ones by $0.12 \AA$ and $0.06 \AA$, respectively. The $\mathrm{Ru}-\mathrm{C}$ distances are also computed to be slightly longer than the experimental ones, by $0.06 \AA, 0.03 \AA, 0.06 \AA$ and of $0.05 \AA$ for the $\mathrm{Ru}(1)-\mathrm{C}(1), \mathrm{Ru}(2)-\mathrm{C}(8), \mathrm{Ru}(3)-\mathrm{C}(12)$ and $\mathrm{Ru}(4)-\mathrm{C}(11)$ bond lengths, respectively. A better agreement is found for the distances of the carbon bridge. The slight distortion of the central carbon square is well reproduced, with two short bonds (C(3)-C(9) and $\mathrm{C}(4)-\mathrm{C}(9))$ of $1.465 \AA$ and two slightly longer bonds (C(3)-C(12) and C(4)-C(12)) of $1.497 \AA$ and $1.484 \AA$, respectively. This distortion is mainly due to the steric hindrance of the ruthenium fragment directly bonded to the square. Finally, the $\{-\mathrm{C}(4)-\mathrm{C}(5) \equiv \mathrm{C}(6)-\mathrm{C}(7) \equiv \mathrm{C}(8)-\mathrm{Ru}(2)\}$ chain is computed to have a more important cumulenic character than in the X-ray structure of $4\left(\mathrm{AsF}_{6}\right)_{2}$, with the single and triple bonds computed shorter and longer by $0.02 \AA$.

Oxidation of $4^{2+}$ leads to some modification of the metalligand distances. Indeed, the Ru-P bond lengths in $4^{3+}$ lengthen by $0.02 \AA$. The Ru-C distances are also affected upon oxidation with the $\mathrm{Ru}(1)-\mathrm{C}(1), \mathrm{Ru}(2)-\mathrm{C}(8), \mathrm{Ru}(3)-\mathrm{C}(12)$ and $\mathrm{Ru}(4)-\mathrm{C}(11)$ bond lengths computed shorter by $0.02 \AA$ than in $4^{2+}$. To a lesser extent, the single C-C bonds are found slightly shorter and the triple $\mathrm{C} \equiv \mathrm{C}$ bonds slightly longer in the tricationic system.

In the reduced species $4^{+}$, the metallic fragments are affected differently. Indeed, the $\mathrm{Ru}(1)-\mathrm{C}(1)$ and $\mathrm{Ru}(2)-\mathrm{C}(8)$ distances are computed longer by $0.04 \AA$ compared to the dicationic complex, whereas the $\mathrm{Ru}(3)-\mathrm{C}(12)$ and $\mathrm{Ru}(4)-\mathrm{C}(11)$ distances are lengthened by only $0.01 \AA$. The carbon skeleton is also affected. The single and triple C-C bonds are computed slightly longer and shorter in the monocationic species than in the dicationic one. Moreover, the bond lengths in the central carbon square are strongly modified upon reduction, with a lengthening of $0.02 \AA$ of the $\mathrm{C}(3)-\mathrm{C}(12)$ and $\mathrm{C}(4)-\mathrm{C}(9)$ distances and a shortening of $0.03 \AA$ of the $\mathrm{C}(3)-\mathrm{C}(9)$ and $\mathrm{C}(4)-\mathrm{C}(12)$ distances. These geometrical changes suggest that upon oxidation of $4^{2+}$, both the ruthenium centers and the $\mathrm{C}_{12}$ carbon backbone should be affected, whereas its reduction should be mainly centered on the $\mathrm{Ru}(1)$-carbon-Ru(4) string and on the central carbon square.

Examination of the first frontier molecular orbitals of $4^{2+}$, plotted in Figure 4, can be informative and help to rationalize the geometrical changes observed upon the reduction and oxidation of $4^{2+}$. A large HOMO-LUMO energy gap (ca. 1.10 $\mathrm{eV})$ is computed for $4^{2+}$. This confirms the thermodynamic stability of this complex in its singlet state electronic configuration. A Mulliken atomic decomposition analysis of the $\mathrm{HOMO}$ and HOMO-1 of $4^{2+}$, given in Table S3, reveals delocalization over the entire $\mathrm{Ru}_{4}-\mathrm{C}_{12}$ skeleton, almost equally distributed over the metal and carbon atoms (see Figure 4, bottom). They are $\pi$ type in character and antibonding between the ruthenium atoms and the adjacent carbon atoms. They are also bonding between the carbon atoms $\mathrm{C}(1)$ and $\mathrm{C}(2), \mathrm{C}(9)$ and $\mathrm{C}(10), \mathrm{C}(7)$ and $C(8)$ and between $C(10)$ and $C(11)$. Their partial depopulation upon oxidation will affect the whole backbone as computationally observed (see above).

As can be seen on top of Figure 4, the LUMO and LUMO+1 of $4^{2+}$ are $\pi$-type in character and are heavily weighted on the carbon chain (75 and $69 \%$, respectively) and to a lesser extent on the metal atoms (14 and $21 \%$, respectively). As previously observed for analogous bimetallic systems, these two MOs are reminiscent of the two $\pi^{*}$-MOs of the cyclobutadiene dication $\left(\mathrm{C}_{4} \mathrm{H}_{4}\right)^{2+} \cdot{ }^{15}$ This explains the change in the C-C distances of the square upon reduction.

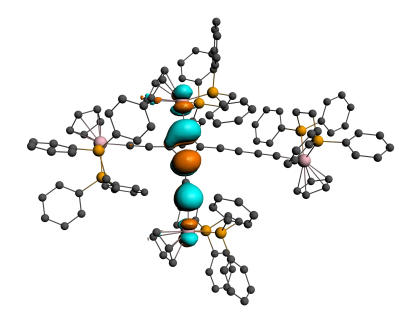

LUMO +1: $-5.78 \mathrm{eV}, 21 / 69$

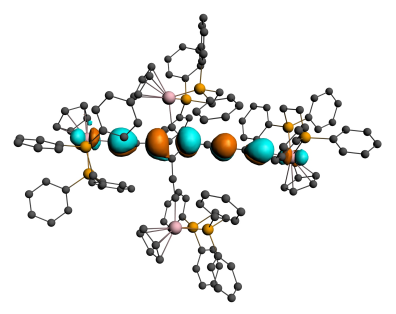

LUMO: -6.23 eV, 14 / 75 

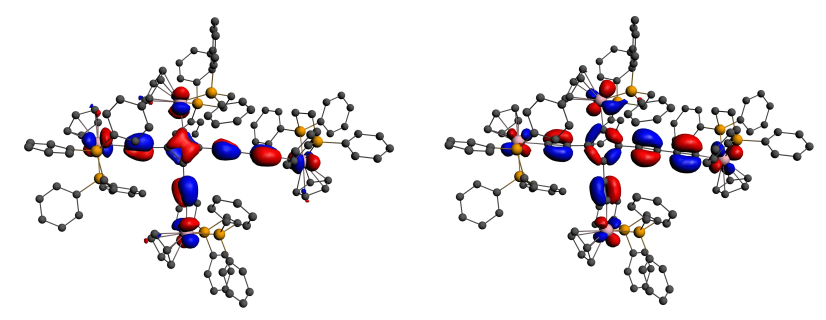

HOMO: -7.32 eV, 40 / 30

HOMO-1: -7.56 eV, 36 / 36

Figure 4. Contour plots, energies $(\mathrm{eV})$ and $\mathrm{Ru}_{4} / \mathrm{C}_{12}$ percentage contributions of the first HOMOs and LUMOs of $4^{2+}$ (isocontour value: $\left.\pm 0.03\left[\mathrm{e} / \mathrm{bohr}^{3}\right]^{1 / 2}\right)$.

The spatial distributions of the spin density of $4^{+}$and $4^{3+}$ are shown in Figure 5 (for a detailed atomic spin density distribution, see Table S4 in Supporting Information). In agreement with the previous description of the HOMOs and LUMOs of $4^{2+}$, the unpaired electron in the monocationic species $4^{+}$is delocalized over the Ru1-Ru2 axis with the largest atomic spin densities found on atoms $\mathrm{C}(3)$ and $\mathrm{C}(4)$ of the carbon square, 0.24 and 0.29 e, respectively. By contrast, in the tricationic complex $4^{3+}$, the spin density is mainly localized on the ruthenium centers with 0.13 e on each of the metal atoms.

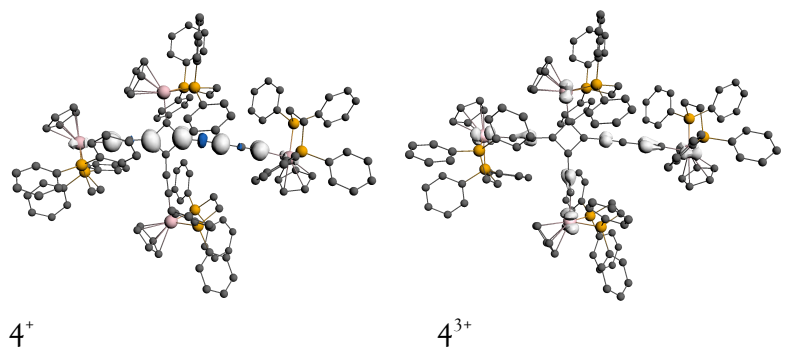

Figure 5. Spatial distribution of the computed spin density of $4^{+}$ (left) and $4^{3+}$ (right). Isocontour value: $\pm 0.004 \mathrm{e} / \mathrm{bohr} 3$.

The first excitation energies were computed using the TDDFT approach for the dicationic complex $4^{2+}$. The most intense electronic excitations (oscillator strength $f \geq 0.05$ ) are given in Table S5. Among them, one is computed at 11490 $\mathrm{cm}^{-1}(870 \mathrm{~nm}, f=0.10)$ and corresponds to a metal-to-ligand charge transfer (MLCT) involving transitions from $\mathrm{d} \pi / \pi$ type orbitals (including the $\mathrm{HOMO}$ ) of the alkynyl-ruthenium fragments to the $\pi^{*}$ type orbitals of the carbon bridge (including the LUMO). A set of two similar intense excitations, at 15962 (626 $\mathrm{nm}, f=0.33)$ and $16626 \mathrm{~cm}^{-1}(601 \mathrm{~nm}, f=0.31)$ are also computed, likewise corresponding to an MLCT involving transitions from the ruthenium-centered $\mathrm{HOMO}-4$ and HOMO-7 orbitals to the delocalized LUMO. A less intense MLCT excitation is computed at $20236 \mathrm{~cm}^{-1}(494 \mathrm{~nm}, f=0.11)$ involving transitions from metal-alkynyl-based MOs to dppe localized MOs.

Finally, we may wonder, what is the disposition of the two holes in $4^{2+}$ ? Do the holes have the cis or the trans disposition? The latter is required both for QCA and for the minimization of the Coulombic repulsion. If the "kink" energy, i.e., energy difference between the cis and trans arrangements of the holes is too small relative to the thermal energy at the temperature of QCA operation, the binary signal transmitted through the cells will become garbled. A glance at the Mulliken atomic net charges indicates unfortunately that the four $\mathrm{Ru}$ atoms are identically positively charged $(c a .+1)$. The excess of positive charge is compensated by adjacent negatively charged carbon atoms (see Figure S2 in Supporting Information).

As a consequence of the coupling mechanism, the new complex $4\left(\mathrm{PF}_{6}\right)_{2}$ is not a symmetric square molecule. Indeed, DFT calculations on a putative symmetric isomer $\left(5^{2+}\right.$, Scheme S1), resulting from a $(\mathrm{C} \gamma-\mathrm{C} \gamma)$ coupling of $3^{+}$, indicate that it is slightly more thermodynamically stable than the asymmetric compound $4^{2+}$ by $5.3 \mathrm{kcal} / \mathrm{mol}$ and displays comparable geometrical and electronic properties (HOMO-LUMO gap of $1.28 \mathrm{eV}$, see Table S6).

7. Redox Properties of $4\left(\mathrm{PF}_{6}\right)_{2}$. The electrochemical behavior of the tetraruthenium complex $4\left(\mathrm{PF}_{6}\right)_{2}$ was studied to determine its redox potentials and hence, the chemical accessibility of the different redox states. The initial scan in the cyclic voltammogram of this complex in the range -1.60 to $1.50 \mathrm{~V}$ [vs. the saturated calomel electrode (SCE)] is characterized by four reversible waves with the same intensity for all of them (Figure 6). This indicates that as the potential decreases from $0.30 \mathrm{~V}$ to $-1.60 \mathrm{~V}$, the dicationic complex $4\left(\mathrm{PF}_{6}\right)_{2}$ undergoes two successive one-electron reductions to form the monocation $4\left(\mathrm{PF}_{6}\right)$ and the neutral complex 4 , in the vicinity of the electrode. In contrast, when the potential increases from $0.30 \mathrm{~V}$ to $1.50 \mathrm{~V}$, the dication is subject to two one-electron oxidations to generate the tri- and tetracationic species $4\left(\mathrm{PF}_{6}\right)_{3}$ and $4\left(\mathrm{PF}_{6}\right)_{4}$, respectively. In total, complex $4\left(\mathrm{PF}_{6}\right)_{\mathrm{n}}$ can be found in five different oxidation states $(0 \leq n \leq 4)$. The redox potentials are collected in Table 1 with those of the binuclear parent 3 .

Comparison of the potentials of the redox couples $3^{0 /+}$ and $3^{+/ 2+}$ with those of $4^{0 /+}$ and $4^{+/ 2+}$ for which the two compounds are bearing the same number of charges, strongly suggests that the frontier orbitals in these two compounds differ in energies and metal vs. carbon bridge contributions. The HOMO involved in the oxidation processes of $4\left(\mathrm{PF}_{6}\right)_{2}$ should be $\mathrm{Ru}_{4} \mathrm{C}_{12}$ centered, while the LUMO involved in the reduction should mainly be bridge centered. This is in agreement with DFT calculations (see above).

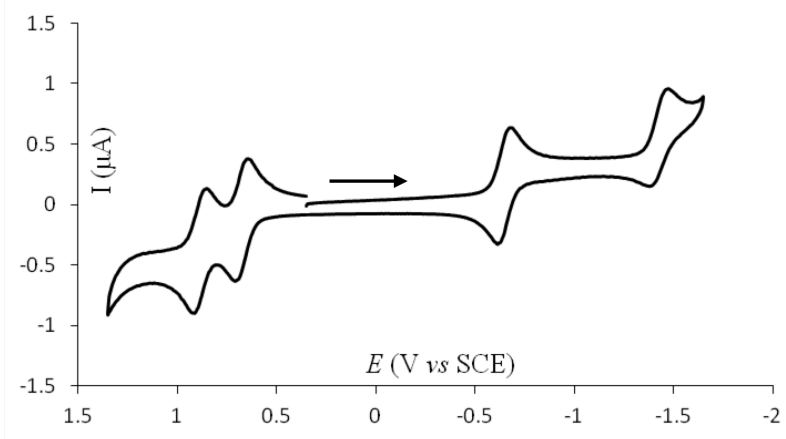

Figure 6. Cyclic voltammogram of $4\left(\mathrm{PF}_{6}\right)_{2}\left(10^{-3} \mathrm{M}\right.$ solution in

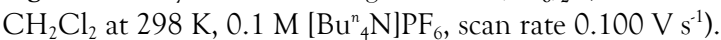


Table 1. Redox Potentials for 3 and $4\left(\mathrm{PF}_{6}\right)_{2}{ }^{\mathrm{a}}$

\begin{tabular}{lllll}
\hline Compd & $E^{0}{ }_{1}$ & $E^{0}{ }_{2}$ & $E^{0}$ & $E^{0}$ \\
\hline 3 & -0.01 & 0.45 & 1.11 & \\
$4\left(\mathrm{PF}_{6}\right)_{2}$ & -1.42 & -0.65 & 0.68 & 0.89 \\
\hline
\end{tabular}

${ }^{a}$ Potentials in $\mathrm{CH}_{2} \mathrm{Cl}_{2}\left(0.1 \mathrm{M}\left[\mathrm{Bu}_{4}{ }_{4} \mathrm{~N}\right]\left(\mathrm{PF}_{6}\right), 25^{\circ} \mathrm{C}\right.$, platinum electrode, sweep rate $0.100 \mathrm{~V} \mathrm{~s}^{-1}$ are given in $\mathrm{V}$ ws SCE; the ferrocene-ferrocenium couple $(0.460 \mathrm{~V}$ ws SCE) was used as an internal reference for the potential measurements.

The potential differences between the redox couples $4^{\circ} / 4^{+}$ and $4^{+} / 4^{2+}\left(\Delta \mathrm{E}^{0}=\mathrm{E}^{0}{ }_{1-} \mathrm{E}^{0}{ }_{2}=1.27 \mathrm{~V}\right)$ in one hand, and $4^{+} / 4^{2+}$ and $4^{2+} / 4^{3+}\left(\Delta \mathrm{E}^{0}=\mathrm{E}_{2-}^{0} \mathrm{E}_{3}^{0}=1.33 \mathrm{~V}\right)$ on the other hand, are very large. The corresponding comproportionation constants are huge $\left(K_{\mathrm{c} 1}=1.1 \times 10^{13}, K_{\mathrm{c} 2}=3.5 \times 10^{22}\right)$, indicating that in each redox state the compound is thermodynamically very stable with respect to charge disproportionation. This property constitutes an important requirement in the QCA quest.

8. Spectroelectrochemistry of $4\left(\mathrm{PF}_{6}\right)_{2}$. Guided by the electrochemical observations on $4\left(\mathrm{PF}_{6}\right)_{2}$, attempts to access the $4^{\circ}$, $4^{+}, 4^{3+}$ and $4^{4+}$ species from $4^{2+}$, by chemical means, using $\mathrm{CoCp}_{2}$ and $\mathrm{Ag}\left(\mathrm{PF}_{6}\right)$ as the reducing and oxidizing agents ${ }^{26}$, respectively, were carried out. Unfortunately, these attempts were unsuccessful, due to partial decomposition of the products.

Table 2. Infrared Data in the $1700-2200 \mathrm{~cm}^{-1}$ Range for $4\left(\mathrm{PF}_{6}\right)_{\mathrm{n}}(n=1-4)$ in $\mathrm{CH}_{2} \mathrm{Cl}_{2}$ at $298 \mathrm{~K}, 0.1 \mathrm{M}\left[\mathrm{Bu}^{n}{ }_{4} \mathrm{~N}\right] \mathrm{PF}_{6}$

\begin{tabular}{llllll}
\hline$n$ & $v_{1}$ & $v_{2}$ & $v_{3}$ & $v_{4}$ & $v_{5}$ \\
\hline 1 & & 1985 & & & \\
2 & 2072 & $1984(\mathrm{sh})$ & 1960 & 1929 & \\
3 & 2064 & & & 1920 & $1890(\mathrm{sh})$ \\
4 & & 1977 & & & \\
\hline
\end{tabular}

IR, UV-vis and NIR spectra of the compounds $4\left(\mathrm{PF}_{6}\right)_{\mathrm{n}}$ were independently collected using spectroelectrochemical methods (dichloromethane, $0.1 \mathrm{M}\left[\mathrm{Bu}^{\mathrm{n}}{ }_{4} \mathrm{~N}\right] \mathrm{PF}_{6}$ ). The starting compound being $4\left(\mathrm{PF}_{6}\right)_{2}$, references to reduction and oxidation in the following are based on this initial +2 charge state. The spectra are provided in the Supporting Information (Figures S3-S9 in Supporting Information) and IR frequencies are summarized in Table 2. The IR spectra collected during the reduction cycle $\left(4^{2+} \rightarrow 4^{+} \rightarrow 4^{0} \rightarrow 4^{+} \rightarrow 4^{2+}\right)$ shows that these processes are far from chemically reversible. In particular the reduction of $4^{+}$ leads to a loss of all characteristic absorptions in the 2200-1700 $\mathrm{cm}^{-1}$ spectral range, indicative of decomposition in the spectroelectrochemical cell (Figures S3 and S4). However, the $4^{2+} \rightarrow 4^{+}$ $\rightarrow 4^{2+}$ cycle is rapid and reversible, and the absorption at 1985 $\mathrm{cm}^{-1}$ may be regarded as a characteristic $v_{\mathrm{CC}}$ stretching mode of $4\left(\mathrm{PF}_{6}\right)$. The significant spectral change on reduction of $4^{2+}$ to $4^{+}$ can be regarded as an indicator that any structural rearrangements are primarily localized to the $\mathrm{C}_{12}$ ligand bridging the ruthenium centers. The significant spectral modification upon reduction indicates that the structural reorganization mainly concerns the $\mathrm{C}_{12}$ ligand which binds the four ruthenium atoms. As the $v_{\mathrm{C} \equiv \mathrm{C}}$ frequency increases upon reduction, the $\mathrm{CC}$ bond distance in $4\left(\mathrm{PF}_{6}\right)$ is expected to be shorter than in $4\left(\mathrm{PF}_{6}\right)_{2}$ in accord with the calculations. However, when applying a constant potential, $4\left(\mathrm{PF}_{6}\right)$ is allowed to sit in the cell and over the time a transformation takes place providing a species denoted 4'( $\left(\mathrm{PF}_{6}\right)$. The monocationic species $4\left(\mathrm{PF}_{6}\right)$ and $4^{\prime}\left(\mathrm{PF}_{6}\right)$ have nearly identical IR spectra and conversion is only seen convincingly in the corresponding UV-vis spectra (see below). The similarity of the IR spectra of the two monocations argues for a limited change in the molecular structure and thus the structural change may be more probably due to relative orientations of the $\mathrm{Cp}(\mathrm{dppe}) \mathrm{Ru}$ moieties or eventually the opening of the cyclobutene ring. Nevertheless, as $4\left(\mathrm{PF}_{6}\right)_{2}$ can be regenerated from either $4\left(\mathrm{PF}_{6}\right)$ and $4{ }^{\prime}\left(\mathrm{PF}_{6}\right)$ by a reversible oxidation, the integrity of the backbone of the molecule is likely preserved.

The redox cycle $\left(4^{2+} \rightarrow 4^{3+} \rightarrow 4^{4+} \rightarrow 4^{3+} \rightarrow 4^{2+}\right)$ is essentially reversible, with almost complete recovery of the initial IR spectrum, indicating little decomposition of the sample during the redox cycle over ca. $12 \mathrm{~h}$ at $20^{\circ} \mathrm{C}$ in the spectroelectrochemical cell. Clearly, there is a small pronounced red shift of the $v_{\mathrm{C} \equiv \mathrm{C}}$ frequencies, indicating a reduced bond order upon oxidation and consequently some C-C bond lengthening (Figure S4). This suggests that the holes generated by oxidation are associated with the HOMO, which is extensively delocalized over the $\mathrm{Ru}_{4} \mathrm{C}_{12}$ backbone and somewhat antibonding between the triply-bonded carbon atoms (see above).

The UV-vis spectrum of $4\left(\mathrm{PF}_{6}\right)_{2}$ is dominated by two intense bands at $16640 \mathrm{~cm}^{-1}\left(601 \mathrm{~nm}, \varepsilon 17600 \mathrm{M}^{-1} \mathrm{dm}^{3}\right)$ and $12060 \mathrm{~cm}^{-1}$ $\left(830 \mathrm{~nm}, \varepsilon 20200 \mathrm{M}^{-1} \mathrm{dm}^{3}\right)$ and a weaker feature at $21460 \mathrm{~cm}^{-1}$ (466 nm, $\varepsilon 5460 \mathrm{M}^{-1} \mathrm{dm}^{3}$, Figure S6 in Supporting Information). The two intense low-energy bands observed in the visible range which are responsible for the deep blue color of the complex can tentatively be assigned to the electronic excitations involving mostly HOMO-n to LUMO MLCT transitions which are computed for $4^{2+}$ (see above). Accordingly, these bands almost disappear upon the sequential reduction of $4\left(\mathrm{PF}_{6}\right)_{2}$ into $4\left(\mathrm{PF}_{6}\right)$ and then to 4 (Figure S6). Alternately, if $4\left(\mathrm{PF}_{6}\right)$ is allowed to stay in the cell at a constant applied potential then a spectral progression is observed with conversion of 4( $\left(\mathrm{PF}_{6}\right)$ to $\mathbf{4}^{\prime}\left(\mathrm{PF}_{6}\right)$ (See Figure $\mathrm{S} 7$ in Supporting Information). The species $4\left(\mathrm{PF}_{6}\right)$ can be re-oxidized to $4\left(\mathrm{PF}_{6}\right)_{2}$, although due to the time scale of the experiment we are unable to confirm whether this re-oxidation occurs through $4\left(\mathrm{PF}_{6}\right)$.

On the other hand, oxidation of $4\left(\mathrm{PF}_{6}\right)_{2}$ to $4\left(\mathrm{PF}_{6}\right)_{3}$ causes a small red shift of the three lowest-energy bands present in the visible range, and a splitting of the band near $16600 \mathrm{~cm}^{-1}$ (Figure S8 in Supporting Information). In contrast, on further oxidation of $4\left(\mathrm{PF}_{6}\right)_{3}$ to $4\left(\mathrm{PF}_{6}\right)_{4}$ a significant blue shift was observed (Figure S8). Moreover, the intensity of the bands decreases upon oxidation. These observations are consistent with the assignment of these bands to electronic excitations involving mostly HOMO-n to LUMO transitions which are computed for $4^{2+}$ (see above). They also suggest that several HOMO-n levels are rather close in energy.

While complexes $4\left(\mathrm{PF}_{6}\right)_{\mathrm{n}}(n=0,1,2$, and 4$)$ are fully transparent in the NIR range between 4000 and $9000 \mathrm{~cm}^{-1}$, the NIR spectrum of the trication $4\left(\mathrm{PF}_{6}\right)_{3}$ displays two bands of very 
weak intensity at $5600 \mathrm{~cm}^{-1}\left(\varepsilon<100 \mathrm{M}^{-1} \mathrm{dm}^{3}\right)$ and $6800 \mathrm{~cm}^{-1}(\varepsilon$ ca. $100 \mathrm{M}^{-1} \mathrm{dm}^{3}$, Figure S9). Due to the low intensity of these absorptions, the corresponding transitions are likely forbidden and thus unlikely to bear any metal-metal or metal-ligand charge-transfer character. These absorptions are instead tentatively assigned to forbidden ligand-field transitions, similar to those previously observed in related $\mathrm{Ru}(\mathrm{III})$ and $\mathrm{Fe}(\mathrm{III})$ analogues. ${ }^{20,27}$

\section{CONCLUSION}

In this contribution, we have reported the synthesis and characterization of the bis(ruthenium)hexatriynediyl $\{\mathrm{Cp}(\mathrm{dppe}) \mathrm{Ru}\}_{2}(\mu-\mathrm{C} \equiv \mathrm{CC} \equiv \mathrm{CC} \equiv \mathrm{C})(3) . \quad$ Despite a large comproportionation constant determined from voltammetry experiments, thus establishing the thermodynamic stability of $3+$, the mixed-valent radical cation could not be isolated. In-situ EPR characterization of $3\left(\mathrm{PF}_{6}\right)$ confirmed full delocalization, and thus classification as a Robin-Day Class-III complex, although the compound is kinetically unstable above $-10^{\circ} \mathrm{C}$. The tetraruthenium complex $4\left(\mathrm{PF}_{6}\right)_{2}$ is formed in essentially quantitative yield, through an intermolecular radical coupling mechanism uniquely involving the all-carbon hexatriynediyl bridge spanning the two ruthenium termini of $3^{+}$. The reaction is regiospecific for the asymmetric isomer, resulting from sequential $(\mathrm{C} \alpha+\mathrm{C} \gamma)$ coupling followed by $(\mathrm{C} \beta+\mathrm{C} \delta)$ coupling to close the cyclobutene ring. The alternate symmetric isomer, resulting from a less sterically-hindered $(\mathrm{C} \gamma+\mathrm{C} \gamma)$ coupling, was not identifiable in crude reaction mixtures. DFT calculations on $3^{+}$ indicate this is likely a consequence of insufficient spin-density at the central $\mathrm{C} \equiv \mathrm{C}$ triple bond. Increasing the steric bulk about the $\mathrm{C} \alpha \equiv \mathrm{C} \beta$ bond by exchange of the $\mathrm{Cp}$ ligand with $\mathrm{Cp}^{*}$ prevents this intermolecular dimerization of the mixed-valent hexadiyndiyl complex, and will be the subject of a future report.

As a consequence of the coupling mechanism, the new complex $4\left(\mathrm{PF}_{6}\right)_{2}$ is not a symmetric square molecule. Nevertheless, this contribution constitutes a proof of concept that activation of polyynediyl complexes containing an odd number of carboncarbon triple bonds may selectively give rise to tetranuclear complexes and, provided that the regioselectivity can be efficiently controlled, symmetric square molecules could be obtained following this strategy.

At this stage, it cannot be concluded that the fully electron delocalized compound $4\left(\mathrm{PF}_{6}\right)_{2}$ is an optimized model of molecular QCA. However, as this compound is very stable with respect to charge disproportionation, it could be of interest to investigate how it could be possible to favor charge separation with respect to charge delocalization in this arrangement. Indeed, charge localization in such compounds may occur at the molecular level with $\mathrm{PF}_{6}$ counter-ions in the vicinity and/or "collectively" as long as the field of the adjacent molecule is sufficient to break the symmetry of the two quantum wells so that the odd electrons (holes) localize in the well of lower energy.

\section{EXPERIMENTAL SECTION}

General data. All manipulations of air-sensitive compounds were performed under an argon atmosphere using standard Schlenk techniques or in an argon-filled Jacomex 532 dry box. Tetrahydrofuran (THF), diethyl ether, toluene, and pentane were dried and deoxygenated by distillation from sodium/benzophenone ketyl. Acetone was distilled from $\mathrm{P}_{2} \mathrm{O}_{5}$. Dichloromethane and dichloroethane were distilled under argon from $\mathrm{P}_{2} \mathrm{O}_{5}$ and then from $\mathrm{Na}_{2} \mathrm{CO}_{3}$. Methanol was distilled from dried magnesium turnings. Potassium tert-butoxide (ACROS) was used without further purification. $\mathrm{Me}_{3} \mathrm{Si}(\mathrm{C} \equiv \mathrm{C})_{3} \mathrm{SiMe}_{3}{ }^{28},\left[\mathrm{FeCp}_{2}\right]\left(\mathrm{PF}_{6}\right)^{29}$ and $\mathrm{Cp}(\mathrm{dppe}) \mathrm{RuCl}^{30}$ were prepared using reported procedures. Infrared spectra were obtained in $\mathrm{KBr}$ discs with a Bruker IFS28 FTIR infrared spectrophotometer (4000-400 $\left.\mathrm{cm}^{-1}\right)$. UV-visible spectra were recorded on a Varian CARY 5000 spectrometer. ${ }^{1} \mathrm{H},{ }^{13} \mathrm{C}$, and ${ }^{31} \mathrm{P}$ NMR spectra were recorded on Bruker AVIII 400 and AVIII 500 NMR multinuclear spectrometers at ambient temperature, unless otherwise noted. Chemical shifts are reported in ppm $(\delta)$ relative to tetramethylsilane, using the residual solvent resonances as internal references. Coupling constants $(J)$ are reported in hertz $(\mathrm{Hz})$. High-resolution mass spectra (HRMS) were recorded with a high-resolution HP 5971/A/5890-II GC/MS spectrometer operating in the ESI+ mode, at the Centre Régional de Mesures Physiques de l'Ouest (CRMPO), Rennes or with a Bruker MicroTOF spectrometer at the University of Waikato, New Zealand. Polyethyleneglycol (PEG) was used as internal reference and dichloromethane was used as solvent. All mass measurements refer to peaks for the most abundant isotopic combination $\left({ }^{1} \mathrm{H},{ }^{12} \mathrm{C},{ }^{31} \mathrm{P},{ }^{102} \mathrm{Ru}\right)$. EPR spectra were recorded on a Bruker EMX-8/2.7 (X-band) spectrometer. Elemental analyses were conducted on a Thermo-FINNIGAN Flash EA 1112 CHNS/O analyzer by the Microanalytical Service of the CRMPO at the University of Rennes 1, France; and at Campbell Micro analytical Laboratory, Dunedin, New Zealand.

X-ray Crystallography. Crystallographic data for the structures were collected at 100(2) K on an Oxford Diffraction Xcalibur diffractometer fitted with Mo K radiation, ( = $0.71073 \AA$ ) for compound 3 and an Oxford Diffraction Gemini diffractometer fitted with $\mathrm{Cu} \mathrm{K}$ radiation $(=1.54178 \AA)$ for 4[AsF6]. Following analytical absorption corrections and solution by direct methods, the structures were refined against $F^{2}$ with full-matrix least-squares using the program SHELXL-97. ${ }^{31}$ For 3, one solvent benzene molecule was found to be disordered over two sites. A second solvent site was modeled as being partially occupied by both benzene and $\mathrm{CH}_{2} \mathrm{Cl}_{2}$ molecules. Site occupancies of disordered molecules were set at 0.5 after trial refinement, with their geometries restrained to ideal values. For 4[AsF6], the atoms of one dppe ligand and one $\mathrm{Ph}$ ring of the other dppe ligand were found to be disordered over two sets of sites corresponding to the two possible configurations of the ethylene bridge. Site occupancies were set at 0.5 after trial refinement.

3. $\mathrm{C}_{71} \mathrm{H}_{61} \mathrm{P}_{4} \mathrm{Ru}_{2} . \quad M=1240.22$, tetragonal, $P 4 / n, a=$ 35.6390(18), $c=9.3223(8) \AA, V=11840.6(13) \AA^{3}, Z=8$, $d_{\text {calc }}=1.391 \mathrm{Mg} / \mathrm{m}^{3}, \mu=0.660 \mathrm{~mm}^{-1}$, crystal size $=0.16 \mathrm{x}$ $0.14 \times 0.10 \mathrm{~mm}^{3}$, reflections collected $=82455$, independent reflections $=13367[R($ int $)=0.1094], 2 \theta_{\max }=55.6^{\circ}, S=$ 
0.943. Final $R$ indices $[I>2 \sigma(I)], R_{1}=0.0718, w R_{2}=$ $0.1600, R$ indices (all data), $R_{1}=0.1514, w R_{2}=0.1915$, $\Delta \rho_{\text {min. } / \max }=2.052$ and -0.696 e. $\AA^{-3}$.

4[AsF6]. $\mathrm{C}_{165} \mathrm{H}_{147} \mathrm{As}_{2} \mathrm{Cl}_{4} \mathrm{~F}_{12} \mathrm{P}_{8} \mathrm{Ru}_{4} \cdot \mathrm{M}=3301.51$, triclinic, $P \overline{1}$, $a=17.2467(7), b=20.2846(7), c=22.0628(9) \AA,=98.452(3)$,

$=94.541(4), \quad=95.517(3)^{\circ}, V=7565.1(5) \AA^{3}, Z=2, d_{\text {calc }}=$

$1.449 \mathrm{Mg} / \mathrm{mm}^{3}, \mu=5.644 \mathrm{~mm}^{-1}$, crystal size $=0.25 \times 0.13 \times 0.05$ $\mathrm{mm}^{3}$, reflections collected $=105301$, independent reflections $=$ $26859[R($ int $)=0.0798], 2_{\max }=134.5^{\circ}, S=1.010$. Final $R$ indices $[I>2(I)], R_{1}=0.0767, w R_{2}=0.2050, R$ indices (all data), $R_{1}$ $=0.1067, w R_{2}=0.2213$, min. $/ \max =4.723$ and $-0.904 \mathrm{e} . \AA^{-3}$.

Spectro-electrochemical measurements. Spectroelectrochemical measurements were made in an OTTLE cell of Hartl design ${ }^{32}$ from $\mathrm{CH}_{2} \mathrm{Cl}_{2}$ solutions containing $0.1 \mathrm{M}$ $\mathrm{NBu}_{4}\left(\mathrm{PF}_{6}\right)$ electrolyte. The cell was filled in an inert atmosphere dry box (Innovative Technology) before being fitted into the sample compartment of a Thermo Scientific 6700 FT-IR/NIR or Thermo Scientific Evolution Array UV-vis spectrometer. Bulk electrolysis was performed with a home-built potentiostat.

Computational details. DFT calculations were performed using the ADF2010.02 (Amsterdam Density Functional) package. ${ }^{33,34}$ Geometries of the bimetallic complexes 3 and $3^{+}$, and the tetrametallic compounds $4^{\text {nt }}(n=1-3)$ were fully optimized using convergence criteria more drastic than default criteria (energy change $<0.0005$ Hartree, atomic position displacement $<0.005 \AA$ A). Electron correlation was treated within the local density approximation (LDA) in the Vosko-Wilk-Nusair parametrization. ${ }^{35}$ The non-local corrections (GGA) of Becke and Perdew (BP86) were added to the exchange and correlation energies, respectively. ${ }^{36}$ The analytical gradient method implemented by Versluis and Ziegler was used. ${ }^{37}$ Spin unrestricted calculations were performed for all the open-shell systems considered. The standard ADF TZP basis set was used for these geometry optimizations and corresponds, explicitly, to a triple- $\xi$ STO basis set for the valence core, augmented with a $2 \mathrm{p}$ polarization function for $\mathrm{H}$, a $3 \mathrm{~d}$ polarization function for $\mathrm{C}, \mathrm{P}$, and a $5 p$ polarization function for $\mathrm{Ru}$. Orbitals up to $1 \mathrm{~s}, 2 \mathrm{p}, 4 \mathrm{p}$ were kept frozen for $\mathrm{C}, \mathrm{P}$ and $\mathrm{Ru}$, respectively. The bonding energies and Cartesian coordinates of each structure are given in Table S6. Computed EPR properties of $3^{+}$were performed using the ESR procedure developed by van Lenthe and coworkers. $^{38}$ The g-tensor components were obtained from selfconsistent spin-restricted DFT calculations after incorporating the relativistic spin-orbit coupling by first-order perturbation theory from a ZORA Hamiltonian. ${ }^{39,40}$ Calculations did not take spin-polarization effects into account. For these calculations, the non-local corrections of Adamo-Barone and of Perdew-Burke-Ernzerhof ( $m$ PBE) were added to the exchange and correlation energies, respectively. ${ }^{41}$ The first electronic excitation energies of $4^{2+}$ were calculated using the time dependent density functional theory (TD-DFT) approach implemented in the ADF package by van Gisbergen and co-workers. ${ }^{39}$ In this case, the functional $\mathrm{mPBE}$ was used. Molecular orbitals were plotted with the ADF-GUI package. ${ }^{34}$

Synthesis of $\{\mathrm{Cp}(\mathrm{dppe}) \mathrm{Ru}\}(\mu-\mathrm{C} \equiv \mathrm{CC} \equiv \mathrm{CC} \equiv \mathrm{C})$ (3). A methanolic $(25 \mathrm{ml})$ suspension of $\mathrm{RuCl}(\mathrm{dppe}) \mathrm{Cp}$ (3) $(0.200 \mathrm{~g}, 0.33$ $\mathrm{mmol}), \mathrm{Me}_{3} \mathrm{SiC} \equiv \mathrm{CC} \equiv \mathrm{CC} \equiv \mathrm{CSiMe}_{3}(0.073 \mathrm{~g}, 0.33 \mathrm{mmol})$ and
KF $(0.039 \mathrm{~g}, 0.67 \mathrm{mmol})$ was heated under reflux for $1 \mathrm{~h}$, after which the mixture was allowed to cool. The yellow precipitate was filtered off and washed with cold $\mathrm{MeOH}(3 \times 10 \mathrm{~mL})$ to give $3(0.158 \mathrm{~g}, \quad 0.264 \mathrm{mmol}, \quad 80 \%)$. Anal.Calcd $\left(\mathrm{C}_{68} \mathrm{H}_{58} \mathrm{P}_{4} \mathrm{Ru}_{2} .0 .5 \mathrm{C}_{6} \mathrm{H}_{6}\right): \mathrm{C}, 68.76 ; \mathrm{H}, 4$ 4.96. Found: $\mathrm{C}, 68.97 ; \mathrm{H}$, 5.16. IR $\left(\mathrm{CH}_{2} \mathrm{Cl}_{2}\right)$ : $(\mathrm{C} \equiv \mathrm{C}) 2063 \mathrm{~cm}^{-1} .{ }^{1} \mathrm{H}$ NMR $\left(\mathrm{C}_{6} \mathrm{D}_{6}\right):$ 1.84$1.87,2.43-2.46\left(2 \times \mathrm{m}, 2 \times 2 \mathrm{H}, 2 \times \mathrm{CH}_{2}\right), 4.56(\mathrm{~s}, 5 \mathrm{H}, \mathrm{Cp})$, 6.85-7.90 (m, 40H, Ph). ${ }^{13} \mathrm{C}$ NMR $\left(\mathrm{C}_{6} \mathrm{D}_{6}\right): \quad 28.23-28.53(\mathrm{~m}$, dppe), $83.16\left(\mathrm{~s}, \mathrm{C}_{5} \mathrm{H}_{5}\right), 96.93(\mathrm{~s}), 102.64\left(\mathrm{t}, \mathrm{Ru}-\mathrm{C} \equiv,{ }^{2} \mathrm{~J}_{\mathrm{CP}}=28\right.$ $\mathrm{Hz}), 127.55-142.91(\mathrm{~m}, \mathrm{Ph}) .{ }^{31} \mathrm{P}$ NMR $\left(\mathrm{C}_{6} \mathrm{D}_{6}\right):$ 85.8. ES-MS (positive ion mode, $\mathrm{MeOH}-\mathrm{NaOMe}, \mathrm{m} / \mathrm{z}$ ): $1202[\mathrm{M}]^{+}$.

Synthesis of $\left[\{\mathrm{Cp}(\mathrm{dppe}) \mathrm{Ru}\}_{4}\left\{\boldsymbol{\mu}-\mathrm{C}_{12}\right\}\right]\left(\mathbf{P F}_{6}\right)_{2} \quad\left(4\left(\mathrm{PF}_{6}\right)_{2}\right)$. $\{$ Ru(dppe $) C p\}_{2}(-\mathrm{C} \equiv \mathrm{CC} \equiv \mathrm{CC} \equiv \mathrm{C})(4)(0.060 \mathrm{~g}, 0.05 \mathrm{mmol})$ and $\left[\mathrm{FeCp}_{2}\right] \mathrm{PF}_{6}(0.016 \mathrm{~g}, 0.05 \mathrm{mmol})$ were dissolved in $6 \mathrm{ml}$ of THF at $-78^{\circ} \mathrm{C}$ when the colour changed immediately from yellow to deep red. After stirring $1 \mathrm{~h}$ at $-78^{\circ} \mathrm{C}$, the solution was slowly allowed to warm up to room temperature over a period of $5 \mathrm{~h}$. When the temperature reached $-10^{\circ} \mathrm{C}$, the colour of the solution changed from deep red to deep blue. After stirring $1 \mathrm{~h}$ at room temperature, hexane $(50 \mathrm{ml})$ was added to the mixture and the resulting precipitate was filtered off and washed with hexane $(2 \times 15 \mathrm{ml})$ to give $\left[\{\mathrm{Ru}(\mathrm{dppe}) \mathrm{Cp}\}_{4}\left\{-\mathrm{C}_{12}\right\}\right]\left[\mathrm{PF}_{6}\right]_{2}\left(4\left(\mathrm{PF}_{6}\right)_{2}\right)$ $(0.062 \mathrm{~g}, 0.046 \mathrm{mmol}, 92 \%)$ as a deep blue powder. Anal. Calcd for $\mathrm{C}_{136} \mathrm{H}_{116} \mathrm{~F}_{12} \mathrm{P}_{10} \mathrm{Ru}_{4}$ : C, 60.67; H, 4.34. Found: C, 60.83; H, 4.44. IR (nujol): (C=C) 2069, $(\mathrm{C}=\mathrm{C}=\mathrm{C}) 1941$, (C=C) 1505, (P-F) $836 \mathrm{~cm}^{-1} .{ }^{1} \mathrm{H}$ NMR $\left(\mathrm{d}_{6}\right.$-acetone, $\left.300 \mathrm{MHz}\right)$ :

2.62, $3.08\left(2 \times \mathrm{m}, 2 \times 8 \mathrm{H}, 2 \times \mathrm{CH}_{2}\right), 4.86(\mathrm{~s}, 5 \mathrm{H}, \mathrm{Cp}), 5.15$ (s, $5 \mathrm{H}, \mathrm{Cp}), 5.20$ (s, 5H, Cp), 5.64 (s, 5H, Cp), 7.01-8.01 (m, 80H, $\mathrm{Ph}) .{ }^{13} \mathrm{C}$ NMR $\left(\mathrm{d}_{6}\right.$-acetone, $\left.150 \mathrm{MHz}, \mathrm{ppm}\right): \quad 29.11-30.00(\mathrm{~m}$, dppe), $86.62\left(\mathrm{~s}, \mathrm{C}_{5} \mathrm{H}_{5}\right), 87.04\left(\mathrm{~s}, \mathrm{C}_{5} \mathrm{H}_{5}\right), 88.26\left(\mathrm{~s}, \mathrm{C}_{5} \mathrm{H}_{5}\right), 89.49(\mathrm{~s}$, $\left.\mathrm{C}_{5} \mathrm{H}_{5}\right), 125.59-143.39\left(\mathrm{~m}, \mathrm{Ph}\right.$ and $\left.\mathrm{C}_{\text {chain }}\right), 159.69,187.15$, 226.10, 258.64, $227.81\left[5 \times \mathrm{s}(\mathrm{br}), \mathrm{C}\right.$ and $\left.\mathrm{C}_{\text {chain }}\right) .{ }^{31} \mathrm{P}$ NMR $\left(\mathrm{d}_{6^{-}}\right.$ acetone, $121 \mathrm{MHz}$ ): 80.7 (broad, 2P), 85.3 (broad, 4P), 94.8 (broad, 2P), -143.2 (septet, $\left.J_{\mathrm{PF}}=710 \mathrm{~Hz}, \mathrm{PF}_{6}\right)$. ES-MS $(\mathrm{m} / \mathrm{z})$ : calcd for $\mathrm{C}_{136} \mathrm{H}_{116} \mathrm{P}_{8} \mathrm{Ru}_{4}$ 1201.661, found $1201.740[\mathrm{M}]^{2+}$.

Synthesis of $\left[\{\mathrm{Cp}(\mathrm{dppe}) \mathrm{Ru}\}_{4}\left\{\boldsymbol{\mu}-\mathrm{C}_{12}\right\}\right]\left(\mathrm{PF}_{6}\right)_{2} \quad\left(6\left(\mathrm{AsF}_{6}\right)_{2}\right)$. $\left[\{\mathrm{Cp}(\mathrm{dppe}) \mathrm{Ru}\}_{4}\left\{-\mathrm{C}_{12}\right\}\right]\left(\mathrm{PF}_{6}\right)_{2}\left(4\left(\mathrm{PF}_{6}\right)_{2}\right)(0.060 \mathrm{~g}, 0.04 \mathrm{mmol})$ and 100 equiv of $\mathrm{KAsF}_{6}(0.916 \mathrm{~g}, 4.00 \mathrm{mmol})$ were dissolved in acetone. After stirring the solution for $10 \mathrm{~min}$ the solvent was removed to dryness. Extraction with $\mathrm{CH}_{2} \mathrm{Cl}_{2}(3 \times 5 \mathrm{~mL})$ provide $6\left(\mathrm{AsF}_{6}\right)_{2}$ as a deep blue powder $(0.063 \mathrm{~g}, 0.04 \mathrm{mmol}, 95 \%)$. IR and ${ }^{31} \mathrm{P}$ NMR spectra confirm the absence of the $\mathrm{PF}_{6}$ anion in the product. Single crystals suitable for XRD were grown by slow diffusion of benzene in solutions of $6\left(\mathrm{AsF}_{6}\right)_{2}$ in dichloromethane.

\section{SUPPORTING INFORMATION.}

Contour plots and energies of the frontier orbitals of 3 (Table S1), the IR, UV-vis spectra of the reduction and oxidation cycles of $4\left(\mathrm{PF}_{6}\right)_{\mathrm{n}}(n=0,1,2,3$, 4; Figure S2-S7), the NIR spectrum of $4(\mathrm{PF} 6) 3$ (Figure S8), CIF file for 3 and $4\left(\mathrm{PF}_{6}\right)_{2}$. This material is available free of charge via the Internet at http://pubs.acs.org. Full details of the structure determination have also been deposited with the Cambridge Crystallographic Data Centre as CCDC 928914 and 928915 . Copies of this information may be obtained free of charge from The Director, CCDC, 12 Union Street, Cam- 
bridge CB2 1EZ, U.K. (fax, +44-1223-336-033; e-mail, deposit@ccdc.cam.ac.uk).

\section{ACKNOWLEDGMENT.}

The MNERT (Ph.D. grants to A.B. and F.G.) and the Université Européenne de Bretagne (UEB, travel grant to A.B.) are acknowledged for financial support. We thank the Centre National de la Recherche Scientifique (CNRS), the Australian Research Council (ARC), and Engineering and Physical Sciences Research Council (EPSRC) for support of this work. K.C., J.-F.H., and F.G. thank the French GENCI-CINES and GENCI-IDRIS centers for highperformance computing resources (Grant 2012-80649). P.J.L. holds an EPSRC Leadership Fellowship. We thank Johnson Matthey plc, Reading, UK, for a generous loan of $\mathrm{RuCl}_{3}, \mathrm{nH}_{2} \mathrm{O}$. Part of this work was conducted within the scope of the CNRS Associated European Laboratory "Molecular Materials and Catalysis (MMC)" involving the Department of Chemistry of Durham University and the Institut des Sciences Chimiques de Rennes.

\section{REFERENCES}

1. Lent, C. S.; Tougaw, P. D.; Porod, W. J.; Bernstein, G. H., Nanotechnology 1993, 4, 49-57.

2. Tougaw, P. D.; Lent, C. S.; Porod, W. J., J. Appl. Phys. 1993, 14, 3558-3566.

3. Jiao, J.; Long, G. J.; Rebbouh, L.; Grandjean, F.; Beatty, A. M.; Felhner, T. P., J. Am. Chem. Soc. 2005, 127, 17819-17831.

4. (a) Leininger, S.; Olenyuk, B.; Stang, P. J., Chem. Rev. 2000, 100, 853-908. (b) Holliday, B. J.; Mirkin, C. A., Angew. Chem., Int. Ed. 2001, 40, 2022-2043. (c) Cotton, F. A.; Lin, C.; Murillo, C. A., Acc. Chem. Res. 2001, 34, 759-771. (d) Jiao, J.; Long, G. J.; Grandjean, F.; Beatty, A. M.; Fehlner, T. P., J. Am. Chem. Soc. 2003, 125, 7522 7523. (e) Cotton, F. A.; Daniels, L. M.; Lin, C.; Murillo, C. A., J. Am. Chem. Soc. 1999, 121, 4538-4539. (f) Lau, V. C.; Berben, L. A.; Long, J. R., J. Am. Chem. Soc. 2002, 124, 9042-9043. (g) Oshio, H.; Onodera, H.; Tamada, O.; Mizutani, H.; Hikichi, T.; Ito, T., Chem. Eur. J. 2000, 6, 2523-2530. (h) Oshio, H.; Onodera, H.; Ito, T., Chem. Eur. J. 2003, 9, 3646-3650. (I) Nemykin, V. N.; Rohde, G. T.; Barrett, C. D.; Hadt, R. G.; Bizzarri, C.; Galloni, P.; Floris, B.; Nowik, I.; Herber, R. H.; Marrani, A. G.; Zanoni, R.; Loim, N. M., J. Am. Chem. Soc. 2009, 131, 14969-14978. (j) Lu, Z.Z.; Lee, C.-C.; Velayudham, M.; Lee, L.W.; Wu, J.Y.; Kuo, T.-S.; Lu, K.-L., Chem. Eur. J. 2012, 18, 15714 15721.

5. Connelly, N. G., Chem. Soc. Rev. 1989, 18, 153-185.

6. Astruc, D., Electron Transfer and Radical Processes in Transition-Metal Chemistry. VCH: New York, 1995.

$7 . \quad$ Schauer, P. A.; Low, P. J., Eur. J. Inorg. Chem. 2012, 390411.

8. (a) Paul, F.; Lapinte, C., Coord. Chem. Rev. 1998, 178-180, 427-505. (b) Akita, M.; Koike, T., Dalton Trans. 2008, 3523-3530. (c) Low, P. J., Coord. Chem. Rev. 2013, 257, 1507-1532. (d) Halet, J.-F.; Lapinte, C., Coord. Chem. Rev. 2013, 257, 1584-1613. (e) Lu, Y.; Quardokus, R.; Lent, C. S.; Justaud, F.; Lapinte, C.; Kandel, S. A., J. Am. Chem. Soc. 2010, 132, 13519-13524. (f) Quardokus, R. C.; Lu, Y.; Wasio, N. A.; Lent, C. S.; Justaud, F.; Lapinte, C.; Kandel, S. A., J. Am. Chem. Soc. 2012, 137, 1710-1714.

9. Lapinte, C., J. Organomet. Chem. 2008, 693, 793-801.

10. Coat, F.; Lapinte, C., Organometallics 1996, 15, 477-480.

11. (a) Le Narvor, N.; Toupet, L.; Lapinte, C., J. Am. Chem. Soc. 1995, 117, 7129-7138. (b) Brady, M.; Weng, W.; Zhou, Y.; Seyler, J. W.; Amoroso, A. J.; Arif, A. M.; Böhme, M.; Frenking, G.; Gladysz, J. A., J. Am. Chem. Soc. 1997, 119, 775-788. (c) Kheradmandan, S.; Heinze, K.; Schmalle, H. W.; Berke, H., Angew. Chem., Int. Ed. Engl. 1999, 38, 2270-2273.
12. Bruce, M. I.; Low, P. J.; Costuas, K.; Halet, J.-F.; Best, S. P.; Heath, G. A., J. Am. Chem. Soc. 2000, 122, 1949-1962.

13. (a) Akita, M.; Chung, M.-C.; Sakurai, A.; Sugimoto, S.; Terada, M.; Tanaka, M.; Moro-oka, Y., Organometallics 1997, 16, 4882-4888. (b) Fitzgerald, E. C.; Brown, N. J.; Edge, R.; Helliwell, M.; Roberts, H. R.; Tuna, F.; Beeby, A.; Collison, D.; Low, P. J.; Whiteley, M. W., Organometallics 2012, 31, 157-169. (c) Xu, G. L.; Crutchley, R. J.; DeRosa, M. C.; Pan, Q.J.; Zhang, H.-X.; Wang, X.; Ren, T., J. Am. Chem. Soc. 2005, 127, 13354-13365. (d) Ying, J.-W.; Liu, I. P.-C.; XI, B.; Song, Y.; Campana, C.; Zuo, J. L.; Ren, T., Angew. Chem. Int. Ed. 2010, 49, 954-957. (e) Sun, J.; Shaner, S. E.; Jones, M. K.; O'Hanlon, D. C.; Mugridge, J. S.; Hopkins, M. D., Inorg. Chem. 2010, 49, 1687 1698. (f) Venkatesan, K.; Berke, H., J. Am. Chem. Soc. 2010, 132, 3115-3127.

14. Szafert, S.; Paul, F.; Meyer, W. E.; Gladysz, J. A.; Lapinte, C., C. R. Chimie 2008, 11, 693-701.

15. Bruce, M. I.; Costuas, K.; Gendron, F.; Halet, J.-F.; Jevric, M.; Skelton, B. W., Organometallics 2012, 31, 6555-6566.

16. Burgun, A.; Gendron, F.; Roisnel, T.; Sinbandhit, S.; Costuas, K.; Halet, J.-F.; Bruce, M. I.; Lapinte, C., Organometallics 2013, Submitted, 1866-1875.

17. Gendron, F.; Burgun, A.; Skelton, B. W.; White, A. H.; Roisnel, T.; Bruce, M. I.; Halet, J.-F.; Lapinte, C.; Costuas, K., Organometallics 2012, 31, 6796-6811.

18. (a) Bruce, M. I.; Hall, B. C.; Kelly, B. D.; Low, P. J.; Skelton, B. W.; White, A. H., J. Chem. Soc., Dalton Trans. 1999, 3719-3728. (b) Bruce, M. I.; Kramarczuk, K. A.; Skelton, B. W.; White, A. H., J. Organomet. Chem. 2010, 695, 469-473. (c) Zheng, Q. L.; Bohling, J. C.; Peters, T. B.; Frisch, A. C.; Hampel, F.; Gladysz, J. A., Chem. Eur. J. 2006, 12, 6486-6505.

19. Robin, M. B.; Day, P., Adv. Inorg. Chem. Radiochem. 1968, 10, 247-422.

20. Paul, F.; Ellis, B. E.; Bruce, M. I.; Toupet, L.; Roisnel, T.; Costuas, K.; Halet, J.-F.; Lapinte, C., Organometallics 2006, 25, 649. 665 .

21. Bruce, M. I.; Costuas, K.; Davin, T.; Ellis, B. E.; Halet, J.-F.; Lapinte, C.; Low, P. J.; Smith, K. M.; Skelton, B. W.; Toupet, L.; White, A. H., Organometallics 2005, 24, 3864-3881.

22. (a) Rieger, P. H., Coord. Chem. Rev. 1994, 135/136, 203 286. (b) Dong, T.-Y.; Sohel, C.-C.; Hwang, M.-Y.; Lee, T. Y.; Yeh, S.-K.; Wen, Y.S., Organometallics 1992, 11, 573-582. (c) Dong, T.-Y.; Hendrickson, D. N.; Pierpont, C. G.; Moore, M. F., J. Am. Chem. Soc. 1986, 108, 963-971. (d) Le Stang, S.; Paul, F.; Lapinte, C., Organometallics 2000, 19, 1035-1043. (e) Weyland, T.; Costuas, K.; Toupet, L.; Halet, J.-F.; Lapinte, C., Organometallics 2000, 19, 4228-4239. (e) Costuas, K.; Cador, O.; Justaud, F.; Le Stang, S.; Paul, F.; Monari, A.; Evangelisti, S.; Toupet, L.; Lapinte, C.; Halet, J.-F., Inorg. Chem. 2011, 50, 12601-12622.

23. Bruce, M. I.; Morris, J. C.; Parker, C. R.; Skelton, B. W., J. Organomet. Chem. 2011, 696, 3292-3295.

24. Szafert, S.; Gladysz, J. A., Chem. Rev. 2006, 106, PR1-PR33.

25. Bruce, M. I.; Dean, C.; Duffy, D. N.; Humphrey, M. G.; Koutsantonis, G. A., J. Organomet. Chem. 1985, 295, c40-c44.

26. Connelly, N. G.; Geiger, W. E., Chem. Rev. 1996, 96, 877.

910.

27. Paul, F.; Toupet, L.; Thépot, J.-Y.; Costuas, K.; Halet, J.-F.; Lapinte, C., Organometallics 2005, 24, 5464-5478.

28. Rubin, Y.; Lin, S. S.; Knobler, C. B.; Anthony, J.; Boldi, A. M.; Diederich, F., J. Am. Chem. Soc. 1991, 113, 6943-6949.

29. Connelly, N. G.; Geiger, W. E., Chem. Rev. 1996, 96, 877 -

910.

30. Alonso, A. G.; Reventós, L. B., J. Organomet. Chem. 1988, $328,249-254$.

31. Sheldrick, G. M., Acta Cryst. 2008, A64, 112-118.

32. Krejeik, M.; Danek, M.; Hartl, F., J. Electroanal. Chem. 1991, 317, 179-187. 
33. Te Velde, G.; Bickelhaupt, F. M.; van Gisbergen, S. J. A.; Fonseca Guerra, C.; Baerends, E. J.; Snijders, J. G.; Ziegler, T. J., Comput. Chem. 2001, 22, 931-967.

34. ADF2010.02 SCM, Theoretical Chemistry, Vrije Universiteit, Amsterdam, The Netherlands, http://www.scm.com

35. Vosko, S. H.; Wilk, L.; Nusair, M., Can. J. Phys. 1980, 12001211.

36. Becke, A. D., Phys. Rev. 1988, A38, 3098-3200.

37. Verluis, L.; Ziegler, T., J. Chem. Phys. 1988, 88, 322-328.

38. (a) van Lenthe, E.; van der Avoird, A.; Wormer, P. E. S., J.
1998, 108, 4783-4796. (b) Autschbach, J.; Pritchard, B., Theor. Chem. Acc. 2011, 129, 453-466.

39. van Gisbergen, S. J. A.; Snijders, J. G.; Baerends, E. J., Comput. Phys. Comm. 1999, 118, 119-138.

40. van Lenthe, E.; Baerends, E. J., J. Comput. Chem. 2003, 24 , $1142-1156$.

41. (a) Adamo, C.; Barone, V., J. Chem. Phys. 2002, 116, 5933 5940. (b) Perdew, J. P.; Burke, K.; Ernzerhof, M., Phys. Rev. Lett. 1996, 77, 3865-3868.

\section{Chem. Phys.}




\section{Straightforward Access to Tetrametallic Complexes with a Square Array by Oxidative Dimerization of Organometallic Wires}

Alexandre Burgun, ${ }^{\ddagger}{ }^{\dagger}$ Frédéric Gendron, ${ }^{\ddagger}$ Phil A. Schauer, ${ }^{\S}$ Brian W. Skelton, ${ }^{\ddagger}$ Paul J. Low, ${ }^{\S}$ Karine

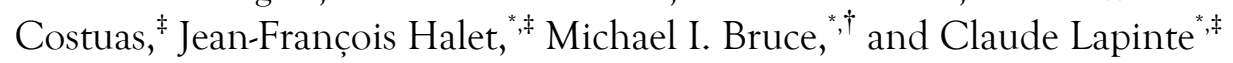

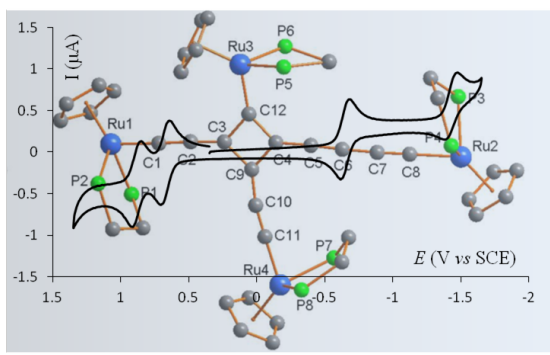

